\title{
A Qualitative Study on Experiences of Parenthood Among Mothers of Early School-Age Children
}

\author{
Hyun-Sim Doh ${ }^{1}$, Seung-Min Song ${ }^{2}$, Woon Kyung Lee ${ }^{1}$, Min-Jung Kim ${ }^{3}$, \\ Nana Shin ${ }^{1}$, Tae Woo Kim ${ }^{1}$ \\ Department of Child Development, Ewha Womans University, Seoul, Korea ${ }^{1}$ \\ Department of Child \& Family Welfare, The University of Suwon, Hwaseong, Korea ${ }^{2}$ \\ Department of Child Welfare, Namseoul University, Cheonan, Korea ${ }^{3}$

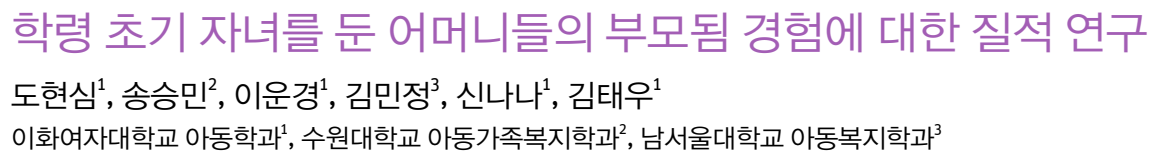

Objective: The purpose of this study was to gain an understanding of parenthood of mothers of early school-age children, with emphasis on cognitive, behavioral, and emotional aspects of parenthood.

Methods: Nineteen mothers whose children were 1st and 2nd grade elementary school children participated in this study. Data were collected through individual in-depth interviews. During the interview, mothers were asked to speak freely about their experiences as parents of early-school age children, including parenting beliefs, parenting behaviors, and emotional experiences related to parenting. These interviews were transcribed verbatim and analyzed in a thematic way using MAXQDA.

Results: Using qualitative methods, five major themes were emerged: (1) Recognizing the role of parents as a supporter of growth; (2) recognizing parenthood of the present generation that imposes expanded roles to mothers; (3) co-parenting of early school-age children and marital relationship; (4) co-existence of different parenting styles based on specific mother-child interaction situations; (5) experiencing a wide spectrum of emotions including anxiety, guilt, and depression, as well as happiness.

Conclusion: This study revealed the unique cognitive, behavioral, and emotional aspects of parenthood experienced by mothers with early school-age children. Results of this study can fill a gap in our understanding of parenthood of mothers when their children entered into the new developmental stage of middle childhood. The results could also be used as a basis for developing parent education and family relationship programs.

Keywords: parenthood, early school-age, parenting beliefs, parenting efficacy, parenting stress, parenting behavior

Corresponding Author: Seung-Min Song, Department of Child \& Family Welfare, The University of Suwon, 17, Wauan-gil, Bongdan-eup, Hwaseong-si, Gyeonggi-do, Korea

E-mail: smsong@suwon.ac.kr
(C)The Korean Association of Child Studies

This is an Open Access article distributed under the terms of the Creative Commons Attribution Non-Commercial License (http:// creativecommons.org/licenses/by-nc/4.0) which permits unrestricted noncommercial use, distribution, and reproduction in any medium, provided the original work is properly cited. 


\section{서론}

부모됨(parenthood)이란 무엇을 의미하며, 이로 인해 부모는 어떠한 경험을 하게 되는가? 일반적으로 부모됨을 정의할 때 특히 강조되는 것은 자녀의 생산, 양육, 교육 및 보호와 같은 넓은 범위의 의무적 측면이나(Bigner \& Gerhardt, 2014), 전 생 애적 관점에서 부모됨은 이미 성인기에 도달한 부모 자신의 인지적, 행동적, 정서적 발달에도 커다란 영향을 미칠 뿐 아니 라 개인으로서의 자아정체감에까지 영향을 미치는 부모로서 의 역할임이 보고되고 있다(Demick, 2002). 부모됨을 통해 부 모는 부모역할에 수반되는 기쁨, 좌절, 자신감, 두려움 등을 포함한 다양한 감정을 경험하며, 자녀의 발달이 진행됨에 따 라 부모에게 주어지는 지속적인 도전들에 맞서 새로운 능력 을 발달시킬 수 있는 기회를 직면하게 된다(Bornstein, 2002; Umberson, Pudrovska, \& Reczek, 2010).

부모됨은 성인의 다음 세대를 육성하려는 발달적 욕구로도 설명되어 왔으며(Erikson, 1963), 대다수의 우리나라 성인들은 부모가 되는 것을 인생에서 반드시 필요한 경험으로 인식해 왔다(J. Park, 2014). 이와 동시에 현대사회에서 부모됨은 어려 운 경제 여건, 맞벌이 가정의 증가, 교육비의 증가, 지나친 경 쟁 등과 같은 여러 가지 고충들로 인해서 어려운 것으로 인식 되고 있으며(Y. Park, Choi, Yang, Na, \& Kim, 2005; Woo, 2013), 특히 사회경제적 불안이 가중되면서 가정을 경제적으로 유지 하고 부모역할을 수행하는 일을 커다란 부담으로 여기는 경향 도 초래되고 있다. 지난 2015년, 인구 1,000명당 혼인율은 5.9 명으로 역대 최저치를 기록하였으며(Statistics Korea, 2016), 자 녀를 원하지 않는 미혼남녀의 비율 또한 지속적으로 늘어나 고 있고, 기혼 여성 중 자녀가 꼭 필요하다고 응답한 비율은 과 반수 이하에 불과한 것으로 보고되고 있다(Korea Institute for Health and Social Affairs, 2012). 이와 같이, 이론적으로 성인기 의 중요한 발달과업으로 여겨 왔던 부모됨에 대한 인식이 흔 들리는 이 시점에 실제 부모가 된 어른들이 부모로서의 역할 을 어떻게 지각하고 있으며, 부모됨의 과정에서 구체적으로 어떠한 경험을 하게 되는지 심층적으로 살펴볼 필요가 있다.

무엇보다도 부모됨을 이해하는 데 자녀의 발달단계를 고려 하는 것은 매우 중요하다(Galinsky, 1981). 자녀의 발달단계 중 에서도 학령 초기는 아동이 공교육 과정에 진입하는 시기로 아동은 또래관계의 확장 및 다양한 과업 수행을 비롯한 여러 가지 도전에 직면한다(Doh, Lee, Kim, Choi, \& Lee, 2011). 부 모 또한 자녀의 이전 발달단계인 유아기와 비교하여, 이 시기 에는 아동이 자기조절능력, 사회적 책임감 및 독립심을 기르
도록 새로운 양육방법을 사용하고, 자녀의 학교생활 및 확대 된 대인관계에서 발생할 수 있는 다양한 문제를 해결할 수 있 도록 돕는 조력자의 역할을 수행하는 과정에서 부모로서의 다 양한 역할긴장과 스트레스를 경험하기 쉬운 시기이다(Collins, Madsen, \& Susman-Stillman, 2002; Ha \& Jang, 2010; S. J. Kim et al., 2015). 이는 자녀의 연령과 부모의 안녕감을 관련시켜 살 펴본 연구(Nomaguchi, 2012)에서도 확인되는 것으로, 학령기 자녀의 부모들은 영유아기 자녀를 둔 부모들에 비해 유의하 게 더 낮은 자아존중감, 부모-자녀관계 만족도 및 더 높은 우 울감을 보고하였다. Nomaguchi (2012)는 이러한 결과에 대해 자녀의 학령기에 들어 증가하는 부모-자녀관계 갈등(inter-role conflict)이 영유아기 자녀를 둔 부모들이 흔히 느끼는 역할부 담(role-overload)보다 부모들에게 심리적으로 좀 더 커다란 부 정적 영향을 미치는 것으로 해석하였다. 특히 우리나라의 학 령기 아동들은 학습지, 학원 및 과외를 포함한 사교육에 대다 수 노출되고 있으며, 많은 부모들이 사교육에 대한 정보를 수 집하고 아동의 시간을 적절히 조절하는 역할로 인한 부담을 감당하고 있어(Woo, 2013), 현 우리 사회 학령기 부모들의 부 모됨 경험에 대해 고찰할 필요성이 제기된다.

이와 같이 부모됨 경험과 관련하여 학령 초기를 포함한 학 령기 부모의 새로운 역할 수행과 그에 따른 스트레스, 안녕 감을 다룬 몇몇 연구들이 보고되기는 하나, 주 양육자로서 의 어머니들이 경험하는 학령 초기 부모됨 경험에 관해 살펴 본 국내외 연구는 여전히 매우 부족한 실정이다. 선행 연구들 은 주로 예비 부모로서의 부모됨에 대한 인식 및 부모로서의 전환 경험(Belsky, Ward, \& Rovine, 1986; Delmore-Ko, Pancer, Hunsberger, \& Pratt, 2000; Pancer, Pratt, Hunsberger, \& Gallant, 2000; Won, 1989) 또는 영아기 및 유아기 자녀의 부모로서의 역할 인식 등(Hudson, Elek, \& Fleck, 2001; S.-E. Lee \& Park, 2012; S. Y. Park, 2005) 주로 어린 아동들의 부모를 대상으로 한 경우가 많아, 유아기를 지나 새로운 발달과업을 완수해야 하 는 학령 초기 아동의 부모들이 부모됨과 관련하여 어떠한 경 험을 하고 있는지에 대한 연구는 매우 드문 편이다. 또한 자녀 의 여러 발달단계에서의 부모역할을 다룬 선행 연구들은 대 부분 부모됨 경험에 접근함에 있어 부모의 양육신념을 비롯 한 인지적 특성, 양육행동 및 정서적 특성 중 일부에 초점을 맞 추거나(Newberger, 1980; Nomaguchi, 2012; Pancer et al., 2000; Umberson et al., 2010), 부모됨 경험과 아동 및 부모의 적응 또 는 양육환경적 특성과의 선형적 관계를 다룬 양적 연구에 초 점을 두었다(Bos, van Balen, \& van den Boom, 2004; Repokari et al., 2006; Rholes, Simpson, \& Friedman, 2006; Wood, Desmarais, 
\& Gugula, 2002). 이러한 연구 경향은 상호 복잡하게 영향을 주고받는 인지, 행동, 정서적 체계를 지닌 개인으로서의 부모 됨 경험(Dolan, 2002; Lench, Flores, \& Bench, 2011)을 심층적 으로 이해하기에 어려움을 야기한다. 이는 가족체계 내에서 개인의 발달을 살펴본 많은 기존 연구들 또한 상호적 영향력 을 밝히고자 일방향적이고 선형적인 양적 연구의 한계를 종 종 드러내는 경향과도 일맥상통한다고 볼 수 있다(Crosonoe \& Cavanagh, 2010).

부모됨 경험과 관련하여 인지적 측면에 해당하는 양육신념 은 부모역할 인식, 아동에 대한 관점과 기대, 자녀양육의 목표 및 바람직한 양육행동에 대한 관점을 포함한, 아동과 부모에 대한 광범위한 신념체계를 의미하는 것으로, 부모됨 경험을 통합적으로 이해할 수 있도록 돕는다(Bugental, 1992; Cohen, 2004; Doh, 2012; Sigel \& McGillicuddy-De Lisi, 2002). 이러한 부모의 인지적 구조는 부모가 자신의 경험 및 환경을 해석하 고 정서적, 행동적으로 반응하는 일관적 경향성을 형성하므 로(Haight, Parke, \& Black, 1997; Newberger, 1980), 부모됨은 물론, 나아가 아동의 발달적 결과를 이해하는 데 중요한 역할 을 한다(Clarke-Stewart, 1988; Goodnow, 2002). 부모의 양육신 념은 부모가 성장기에 경험한 양육, 자신이 속한 사회의 문화 등 다양한 체계의 영향으로 형성된다(Bornstein \& Cote, 2006; S. Choi, 2015; Harkness \& Super, 1996; Ko, 2001; Ok \& Kim, 2015). 부모가 아동발달에 부정적 영향을 미칠 수 있는 신념 을 갖고 있는 경우 세대 간 전이를 통해 그대로 전달되기도 하 지만(Simons, Whitbeck, Conger, \& Chyi-In, 1991), 동시에 세 대 간 차이를 낳기도 한다. 예컨대 젊은 어머니 세대와 그들의 어머니 간에는 부모-자녀 간 상호의존성 및 독립성에 대한 관 점에서 문화적 비연속성이 발견되기도 한다(W. Lee \& Hyun, 1999). 특히 자녀 양육관에 대한 전국적 조사(Korea Institute of Childhood and Education, 2008)는 우리 사회에 자녀양육에 대 한 다양한 신념이 혼재할 가능성을 보여주며, 이러한 신념들 이 부모역할을 수행함에 있어 어떤 작용을 하는지 고찰해 볼 필요성을 제기한다. 대다수의 조사대상 부모는 자녀의 성취와 성공에 부모가 미치는 영향력이 매우 크거나 어느 정도 있다 고 대답했으나, 자녀교육에 있어서는 과반수이상이 부모가 자 녀를 이끌어가는 것보다 자녀가 주도하는 방식이 옳다고 응답 함으로써, 현실적인 부모역할과 이상적 교육방법의 필요성을 동시에 인지하고 있을 가능성을 보였다. 또한 과반수에 가까 운 부모들이 자녀의 기가 꺾이지 않도록 원하는 것을 제지하 지 않아야 한다고 응답함과 동시에, 잘못한 경우 체벌을 할 수 있다는 관점에도 과반수이상 동의하여, 혼재된 신념들이 부모
됨 경험에 어떠한 영향을 미치고 있는지 구체적으로 탐색할 필요성을 제기한다.

양육신념은 부모의 양육효능감과 양육스트레스와 같은 심 리적 경험과도 밀접하게 관련되는데, 이는 양육효능감과 양육 스트레스의 정도가 부모가 가지고 있는 바람직한 부모에 대한 신념과 그에 비견한 부모로서의 자신에 대한 인지적 평가에 근거하기 때문이다(Abidin, 1992; Sigel \& McGillicuddy-De Lisi, 2002). 특히 자녀가 학령기로의 전환기에 있는 부모들은 자녀 의 초등학교 적응에 대한 불안과 학업 수행에 대해 염려하는 경향이 있는데, 이는 부모 스스로 자녀의 적응을 도울 방법을 잘 알지 못할 뿐만 아니라 초기 적응이 추후 학교적응과 발달 에 밀접한 관련이 있다고 생각하는 것과 연관되어 있다(Jung \& Ji, 2006; I. J. Kim \& Lee, 2005). 이와 같이 부모의 양육신념, 양육효능감 및 양육스트레스는 모두 부모의 주관적 인식 및 태도와 같은 인지구조에서 비롯되어 서로 밀접하게 관련되므 로, 이러한 개념들을 서로 독립적인 개념으로 간주하고 살펴 보는 것은 부모됨 경험을 적절히 이해하기에 어려움이 따른다 (Crnic \& Low, 2002).

부모됨 경험의 행동적 측면인 양육행동과 관련하여, 학령 초기 자녀의 부모는 보다 직접적으로 자녀를 보호하고 통제했 던 영유아기와 달리 자녀와 책임감을 분담하고 자녀의 자율 성 증진을 강조하는 등 달라진 부모로서의 역할 인식을 가지 고 새로운 양육방법을 사용할 필요가 있다(Maccoby, 1980). 이 와 동시에 부모의 반응적이고 온정적이며 민주적인 양육행동 은 긍정적 부모-자녀관계 및 아동의 발달 결과에 여전히 중요 한 역할을 차지하는 것으로 알려진다(Collins et al., 2002). 양육 신념과 양육행동 간의 밀접한 연관성은 선행 연구들(Abidin, 1992; Kochanska, Kuczynski, \& Radke-Yarrow, 1989; Sigel, 1985) 을 통해 입증되었으나, 부모의 실제 양육행동은 양육신념 외 에도, 아동의 특성, 부모의 성격, 양육지식의 정도, 부모의 경 제적.직업적 특성 등 다양한 요인들의 영향을 받으므로(Crnic \& Low, 2002; Crouter, Helms-Erikson, Updegraff, \& McHale, 1999; Rowe, 2008), 학령 초기 부모의 양육행동에 어떠한 요인 들이 영향을 미치며 이와 관련하여 주양육자인 어머니들이 부 모됨을 어떻게 경험하고 있는지를 살펴볼 필요가 있다. 마찬 가지로, 부모가 자녀양육에 대해 지속적인 대화를 나누고 일 치하는 방법으로 자녀를 키우는 것을 의미하는 부모공동양육 (co-parenting; Doh, 2012) 또한 양육행동적 측면에서 부부가 서로 다른 부모됨 경험을 구성하는 데 중요한 역할을 할 수 있 다. 이는 부모공동양육이 부모가 지각하는 양육의 부담 및 스 트레스의 정도와 밀접하게 관련되며 나아가 부모역할을 수 
행할 수 있는 능력과도 연관되기 때문이다(Cowan \& McHale, 1996).

한편, 부모로서 경험하는 기쁨과 슬픔, 행복감, 우울감 등 은 부모됨 경험의 정서적 측면에 속한다. 관계 안에서 경험되 는 정서는 관계의 특성과 질을 형성하는 데 중요한 역할을 하 며, 경험에 대한 장기적 기억 형성을 돕고, 긍정적.부정적 행 동의 동기를 부여할 수 있다고 알려진다(Dix, 1991; Dolan, 2002). 부모역할로 인한 정서는 부모-자녀관계의 질 및 바람 직한 양육행동을 위한 동기와도 밀접하게 연결되며(Laursen \& Collins, 2009), 부모됨 경험을 이해하는 데 또 다른 중요한 부분이 된다. 이와 관련하여 많은 선행 연구들은 부모인 성 인과 자녀가 없는 성인을 비교하여 부모역할이 성인의 안녕 감 및 긍정적 정서와 관련이 있는지 살펴보았는데, 그 결과 는 일관적이지 않다. 부모인 성인이 자녀가 없는 성인보다 행 복감이 높다는 연구결과들(Nelson, Kushlev, English, Dunn, \& Lyubomirsky, 2013)과 부모역할이 반드시 부모의 긍정적정 서와 안녕감으로 연결되지는 않는다는 연구결과들(Ambert, 2001; S. J. Kim et al., 2015; Montmayor, 1983; Nelson, Kushlev, \& Lyubomirsky, 2014)은 다소 상반된 견해를 밝히고 있다. 후 자의 경우, 연구자들은 자녀의 연령, 자녀의 수 및 사회문화 적 영향을 포함한 다양한 요인이 고려될 필요가 있음을 제안 한다. 특히 부모의 행복감 상승은 자녀의 출생 직후의 기간 에 한정되며(Myrskyla \& Margolis, 2014), 어린 아동의 부모들 이 부모됨에서 겪는 어려움은 높은 수준의 스트레스와 불안 및 우울과 관련이 있고(Hoffenar, Balen, \& Hermanns, 2010), 자 녀가 성장하면서 부모-자녀 간의 반복적인 부정적 상호작용 을 감내해야 하는 것이 어머니의 우울감과 밀접한 관련이 있 다(Patterson \& MacCoby, 1980). 이러한 연구들은 부모로서의 역할긴장을 경험하고(Collins et al., 2002), 부모-자녀 간 갈등 이 이전 시기보다 증가할 가능성이 있는(Nomaguchi, 2012) 학 령 초기 어머니의 정서적 경험에 대해 심층적으로 고찰할 필 요성이 있음을 보여준다. 또한 자녀의 의식주를 공급하기 위 해 많은 금전적 지출을 하는 것은 경제적 어려움과 불만족감, 어머니의 우울과 연결되고(Jackson, Brooks-Gunn, Huang, \& Glassman, 2000; Zimmerman \& Easterlin, 2006), 교육수준이 높 은 부모들일수록 부모로서의 역할을 충실히 이행해야 한다는 마음의 부담감(role captivity)이 더 크다는 점에서(Nomaguchi \& Brown, 2011), 학령 초기 부모들의 정서적 경험을 가족 내 환경 및 사회문화적 맥락을 고려하여 살펴볼 필요성이 제기 된다.

요약하면, 본 연구는 학령 초기 자녀를 둔 어머니들의 주 양
육자로서의 부모됨 경험을 심층적으로 이해하기 위해 양육신 념을 포함한 인지적 측면, 양육행동을 포함한 행동적 측면, 그 리고 긍정적·부정적 정서를 포함한 정서적 측면을 통합하여 접근하고자 하였다. 즉, 공교육으로의 전환기에 속한 학령 초 기 자녀의 부모로서 다양한 역할 긴장을 경험할 가능성이 높 은 어머니들을 대상으로 그들의 부모됨 경험에 대한 인식을 인지적, 행동적, 정서적 측면에 초점을 두어 심층적으로 탐색 하였다.

\section{연구문제}

학령 초기 자녀를 둔 어머니들은 인지적, 행동적, 정서적 측면 에서 부모됨 경험을 어떻게 인식하고 있는가?

\section{연구방법}

\section{연구참여자}

본 연구의 참여자는 서울에 거주하고 있는 초등학교 1,2 학 년 자녀의 주 양육자인 19명의 어머니들로, 눈덩이 표집방법 을 통해 모집되었다. 연구참여자의 특성을 살펴보면, 연령의 범위는 만 33-41세로, 평균 연령은 37.95세 $(S D=2.66)$ 이었 다. 어머니들은 모두 기혼 상태로 전업주부와 취업모는 각각 12 명(63.2\%)과 7명(36.8\%)이었다. 취업모 가운데 4명은 전일 제, 3 명은 반일제로 근무하고 있었다. 자녀수는 두 명의 자녀 를 둔 경우가 14 명(73.7\%)으로 가장 많았으며, 한 자녀가 3 명 (15.8\%), 세 자녀와 네 자녀가 각각 1명(5.3\%)이었다. 학령 초 기에 속하는 자녀의 특성과 관련하여, 초등학교 2학년 자녀를 둔 어머니가 17 명 $(89.5 \%)$, 초등학교 1 학년 자녀를 둔 어머니 가 2 명 $(10.5 \%)$ 이었으며, 남아와 여아는 각각 11 명(57.9\%)과 8 명(42.1\%)이었다. 출생순위는 외동이 3명(15.8\%), 첫째가 7명 (36.8\%), 둘째가 8명(42.1\%), 셋째가 1명 $(5.3 \%)$ 이었다. 연구 참여자들의 구체적 특성은 Table 1에 제시되어 있다.

\section{자료수집}

본 연구는 부모됨과 관련된 반구조화된 면접을 위해 부모됨 경험의 인지적 측면인 양육신념, 행동적 측면인 양육행동, 정 서적 측면인 부모로서 느끼는 행복과 불안감 등을 포함하여 연구주제를 탐색하기 위한 질문내용들을 구성하였다. 연구진 행 과정에서 연구자들은 오프라인과 온라인상에서 지속적으 
Table 1

General Characteristics of Participants

\begin{tabular}{|c|c|c|c|c|c|c|}
\hline \multirow[b]{2}{*}{ ID } & \multirow[b]{2}{*}{ Age } & \multirow[b]{2}{*}{ Working status } & \multirow[b]{2}{*}{ Num. of children } & \multicolumn{3}{|c|}{ Target child } \\
\hline & & & & Grade & Gender & Birth-order \\
\hline 1 & 40 & PT & 4 & 2 & G & $\mathrm{T}$ \\
\hline 2 & 41 & NW & 3 & 2 & B & S \\
\hline 3 & 40 & NW & 2 & 2 & B & S \\
\hline 4 & 34 & NW & 2 & 2 & B & $\mathrm{F}$ \\
\hline 5 & 34 & NW & 2 & 2 & G & $\mathrm{F}$ \\
\hline 6 & 37 & NW & 2 & 2 & G & $\mathrm{F}$ \\
\hline 7 & 38 & NW & 1 & 2 & G & $\mathrm{O}$ \\
\hline 8 & 41 & NW & 2 & 2 & G & $S$ \\
\hline 9 & 40 & FT & 2 & 2 & B & S \\
\hline 10 & 37 & FT & 1 & 2 & B & $\mathrm{O}$ \\
\hline 11 & 38 & NW & 2 & 1 & B & $S$ \\
\hline 12 & 40 & NW & 2 & 2 & B & S \\
\hline 13 & 33 & $\mathrm{NW}$ & 2 & 2 & G & $\mathrm{F}$ \\
\hline 14 & 40 & $\mathrm{NW}$ & 2 & 2 & B & $\mathrm{F}$ \\
\hline 15 & 36 & NW & 2 & 2 & G & $\mathrm{F}$ \\
\hline 16 & 41 & FT & 2 & 1 & B & S \\
\hline 17 & 36 & PT & 2 & 2 & B & $\mathrm{F}$ \\
\hline 18 & 35 & $\mathrm{PT}$ & 1 & 2 & B & $\mathrm{O}$ \\
\hline 19 & 40 & FT & 2 & 2 & $\mathrm{G}$ & $S$ \\
\hline
\end{tabular}

Note. $N=19 . \mathrm{NW}=$ non-working; PT = part time; FT = full time; $\mathrm{G}=$ girl; $\mathrm{B}=$ Boy; $\mathrm{O}=$ only child; $\mathrm{F}=$ first-born child; $\mathrm{S}=$ second-born child; $\mathrm{T}=$ third-born child.

로 소통하였다. 본 연구의 자료는 2015년 12 월에 1 회의 개별 심층면접(individual in-depth interview)을 통해 수집되었다. 연 구참여자를 모집하기 위하여 연구진의 지인 중 초등학교 1,2 학년 자녀를 둔 어머니들에게 연구의 목적과 취지에 대해 설 명한 후 동의 여부를 확인하였다. 연구 참가에 동의한 경우, 이들을 통해 눈덩이표집법을 사용하여 추가 연구참여자를 모 집하였다. 연구참여자가 확정된 후에는 전화로 면접 시간 및 장소를 결정하였으며, 면접 장소는 연구참여자의 편의를 위 하여 어머니의 거주지나 거주지 인근의 조용한 장소를 이용 하였다.

심층면접은 아동학을 전공한 4 명의 박사급 연구원과 1 명의 박사과정생에 의해 실시되었다. 각 연구참여자에 대한 면접은 개인적 친분이 없는 연구자에 의해 진행되었다. 라포(rapport) 를 형성하기 위해 간단한 대화로 면접을 시작하였으며, 이후 연구의 목적 및 방법에 대해 다시 한 번 설명하였다. 본 면접은 사회인구학적인 정보를 포함한 배경정보에 대한 질문으로 시 작하였다. 사전에 계획된 질문들 외에 연구자는 면접 중에 답
변 내용에 따라 필요한 질문들을 추가하였으며 질문의 순서를 바꾸어 면접을 진행하였다. 심층면접을 진행하면서 연구자들 은 자연스럽게 연구참여자에 대한 관찰을 병행하였으며, 후에 분석을 위한 생각을 발전시킬 수 있도록 기록할 만한 비언어 적 행동이 있을 때 메모를 활용하였다(Glaser \& Strauss, 1967). 전사본에는 머뭇거림 혹은 웃음과 같은 연구 참가자의 정서 를 이해할 수 있는 비언어적 표현들을 기록하여, 분석과정에 서 면접의 정서적 맥락을 이해하는 데 활용하였다. 면접 시간 은 1 시간 반에서 두 시간 가량 소요되었으며, 면접 내용은 연 구참여자의 동의하에 녹음한 후 분석을 위하여 전사하였다 (Wolcott, 2001).

\section{자료분석}

본 연구에서는 어머니를 대상으로 한 심층면접의 내용을 전 사하여 분석하였다. 심층면접 내용은 아동학 전공 대학원 석 사과정생들이 면접내용을 외부로 유출하지 않겠다는 서약서 
를 작성한 후 전사하였다. 전사 자료는 연구참여자별 $\mathrm{A} 4$ 용지 $9-21$ 쪽 $(M=14.76, S D=4.13)$ 분량이었다. 자료 분석은 질적 자료 분석 프로그램인 $\mathrm{MAXQDA}$ 를 사용하여 다음과 같은 단 계로 이루어졌다. 첫 번째 단계에서는 각 연구참여자의 전사 자료를 MAXQDA상에서 여러 번 반복하여 읽으면서 메모 기 능을 활용하여 연구참여자들이 가지고 있는 부모됨에 대한 생 각을 전체적으로 파악하였다. 특히 이 단계에서는 개방적 태 도를 가지고자 노력하며 전체 내용을 파악하는 데 집중하였 다. 두 번째 단계에서는 코딩 기능을 이용하여 면접내용을 대 변하는 의미단위를 찾아내었고(줄단위분석), 유사한 의미단 위들을 묶어서 단어나 주제로 표현하였다. 세 번째 단계에서 는 두 번째 단계에서 도출한 하위주제 간 유사점과 차이점을 비교하여 유사한 주제끼리 주제묶음의 방법을 사용하여 분류 하였다. 마지막으로, 주제묶음을 유목화 혹은 대주제로 분류 하였으며, 모든 작업이 끝난 후 전사자료 원본의 내용을 검토 하여 확인하고 재조정하였다. 이러한 과정을 통해 '부모로서 의 역할 인식: 성장의 조력자', '어머니 역할이 커진 나의 세대 부모됨에 관한 인식', '학령 초기 자녀를 둔 부모의 공동양육과 부부관계', '학령 초기 자녀에 대한 양육행동의 혼재', 그리고 '부모로서 느끼는 감정의 스펙트럼'과 같은 다섯 가지 대주제 가 추출되었다.

\section{연구의 타당도와 윤리적 고려}

질적 연구에서 연구의 타당도란 연구참여자들의 경험이 적절 하게 분석되고 기술되었는지를 의미한다(Ganeson, 2006). 이 를 확보하기 위하여 본 연구에서는, Creswell과 Miller (2000) 의 제안에 근거하여 동료 검토(peer review)와 연구참여자 확인 (member checks)을 실시하였다. 동료 검토에는 본 연구의 공동 연구자뿐 아니라 질적 연구 경험이 풍부한 교수 1 인이 참여하 여 연구방법, 의미, 해석에 대해 함께 논의하였으며, 연구참여 자 확인을 위하여 연구참여자 중 2 명에게 분석 결과를 검토하 도록 하였다.

또한, 연구참여자의 권리를 보호하기 위하여 연구목적과 절차, 비밀보장, 면접 자료의 활용 등에 대한 내용을 연구동의 서에 명시하였다. 연구동의서에는 연구에 참가하기로 동의하 였더라도 중단하기를 원하는 경우 언제든지 중단할 수 있음을 포함하였다. 동의 획득 시 2 부의 동의서를 준비하여, 연구자와 연구참여자가 2부 모두에 서명한 후 각각 보관하였다. 그리고 연구참여자의 익명성을 보장하기 위하여 각 연구참여자에게 고유 대체 번호를 부여하였다.

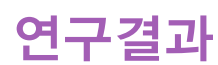

\section{부모로서의 역할 인식: 성장의 조력자}

본 연구에 참가한 대부분의 어머니들은 부모로서 자신의 가장 중요한 역할을 조력자로 인식하고 있었다. 학령기에 들어선 자녀들이 성장과정에서 올바른 방향을 찾아갈 수 있도록 안내 하고, 항상 옆에서 도와주는 역할을 해야 한다고 인식하고 있 었다. 아직은 보호가 필요한 미성숙한 자녀들의 삶에 지나치 게 개입하거나 부모가 주도적으로 자녀의 삶을 이끌어나가기 보다는 성장과정을 지켜보고 옆에서 도와주는 것이 부모의 역 할이라고 인식하고 있었다. 즉, 부모의 보호가 더욱 필요한 영 유아기와 달리 학령기에는 아동이 독립심을 기르도록 학교생 활 및 또래관계에서 발생할 수 있는 다양한 문제를 스스로 해 결할 수 있도록 돕고, 적성을 찾아가도록 안내하는 조력자의 역할을 수행해야 한다는 인식을 가지고 있었다.

아이가 커서도 행복하게 잘 살 수 있게끔 도움도 주고, 안내도 해 주고. 최대한 저의 생각은 내 생각을 애한테 많이 넣지 말자가 되 게 생각이 있거든요. 개가 살 사회랑 제가 살아온 사회는 달라질 거라고 생각을 해서 최대한 기본 개념이나 이런 도덕적인 건 그 렇겠지만 살아가는 방식에 있어선 본인이 찾았으면 좋겠단 생각 이 강해요. 그래서 최대한 그런 거는 범위 넘어가지 않는 선에서 이끌어줄 수 있는? 그런 생각으로 아이를 대하고 있죠. (개별면접, ID 04, 2015년 12월 21일)

부모... 그 아이가 잘 할 수 있게 어느 정도만 옆에서 뮈랄까.. 도와 주는 역할? 그냥 도와주고 그냥 같이 갈 수 있게 동반자인 존재만 됬으면 좋겠어요. 너무도 말고 이 아이의 인생에 대해서 너무 깊 숙이 들어가지도 말고 그렇다고 너무 방관해서 아이를 또 나쁜 길로 이렇게 하는 것도 아니고 옆에만 있는 존재만 돼도 좋을 거 라고 생각하는데 그거가 힘든 것 같아요. 자꾸 아이한테 생각은 늘 이렇게 있는데도 그게 잘 안 되는 것 같아요. (개별면접, $I D 10$, 2015년 12월 19일)

일단은 아이를 잡아그는 부모보다는 뒤에서 밑받침을 든든하게 해줄 수 있는 부모가 되고 싶어요. 그리고 항상 그런 생각이 들거 든요. 아이가 키우면 키울수록 '내 그릇만큼 밖에 못자라는 것 같 다., '부모 그릇만큼 밖에 못자라는 것 같다.', '내가 좀 더 큰 그릇 이면 좋았을걸.' 지금 애가 초등학교 2학년이잖아요, 지금은. 초2 엄마가 되기 전에 좀 더 내 그릇을 초2 엄마로서 그릇을 키워놨으 
면 좋았을 걸 하는 생각이 계속 들어요, 매 순간순간마다. 좀 미리 그릇이 큰 부모가 되어서 (개별면접, ID 17, 2015년 12월 23일)

\section{어머니 역할이 커진 나의 세대 부모됨 경험에 관한 인식}

\section{생활에 바빠서 자상하지 못했던 부모세대}

본 연구에 참가한 어머니들은 자신의 부모들을 바쁘게 살았던 세대로 회상하였으며, 특히 아버지와의 관계에 대해 친밀감을 표현한 참가자는 거의 없었다. 아버지는 대부분 생업에 바빴 고, 교육 및 양육에 대해서는 방관자였다고 기억하였으며, 자 신의 부모세대에 가장으로서의 아버지 역할은 경제적 활동에 집중되어 있는 것이 일반적이었기 때문에 자신의 아버지가 그 세대에서 보편적 아버지 역할을 수행하였다고 생각하고 있었 다.

그때는 저는. 그러니까 엄마 아빠가 그냥 바쁘셔서 저한테 지금. 어릴 때 기억은 그렇게 많이 엄마 아빠가 이렇게 밀... 저를 케어 해 주시지는 않았던 것 같아요. 저는 그냥 시골에서 자랐고, 저 혼 자 친구들과 놀고 혼자 잘 생활했던 것 같아요. 네, 네. 그 때는, 지 금 자라서 보니까, 부모의 손길. 그렇게 많이 느껴지지는 않은 것 같아요. (개별면접, ID 02, 2015년 12월 23일)

우리 아빠 같은 경우에는 거의 우리 클 때 그다지 크게 뮐 한 것 같지 않아요. 그냥 회사 가거나 돈 벌어오고 대부분의 아빠 같은 게 다인 것 같아요. 저희가 공부를 하고... 뭐 양육에 대해서는 그 다지 크게... 그런 것 없었던 것 같아요. (개별면접, $I D$ 10, 2015년 12월 19일)

어머니들은 자신의 아버지를 사회생활과 경제활동에 바빠 서 가정에 무심한 편이었다고 회상하는 한편, 어머니는 대가 족을 부양하는 생활력이 강한 여성으로 인식하고 있었다. 자 녀가 많거나 조부모 및 친인척들이 많은 상황에서 가족을 부 양하느라 생활력이 강해질 수밖에 없었던 어머니의 상황을 인 식하고 있었으며, 자신의 학령기에는 부모에게 세심한 관심과 통제를 받지 않았고 자신의 일을 스스로 독립적으로 해야 했 다고 회상하였다.

저희 엄마는 그런 무관심한 한량처럼 자기만 아는 남편과 애 여 섯을 데리고 살았기 때문에 정말 열심히 사셔야 됐던 거예요. 농
사짓는 분이시거든요. 아버님 돌아가시고 나서도 농사를 혼자 다 하실 정도로 생활력이 강하고. 그 대신 저희 애들한테는 하나에 서 열까지 챙겨주지는 않으시니까 독립심, 자립심 이런 걸 제 입 장에서는 그랬어요. 제가 알아서 스스로 해야 되는 부분이 많았 었고. 그래서 저희 엄마 하소연 하는 거 많잖아요. 그런 거 애기할 때 주로 하는 게 "내가 그렇게 어려운 상황에서도 너희들을 버리 지 않고 이렇게까지 키워준 건 대단한 거야.”라고 애기를 하세요. (개별면접, ID 19, 2015년 12월 23일)

뭔가를 부탁을 할 수가 없었어요. 아빠는 착한 사람이라니까 아 빠한테는 떼를 쓰면 안 되고 제가 판단했을 때. 엄마는 그렇게 힘 들게 아등바등 버티니까 엄마한테도 뮌가 부탁을 하면 안 되고. (개별면접, ID 03, 12월 18일)

\section{부모세대와 달리 자녀와 밀착된 학령기 부모역 할 인식과 양육스트레스}

부모세대가 생활에 바빠서 세심하게 자녀를 양육하고 교육하 는 부모역할에 소홀했다면, 현대의 학령기 자녀를 둔 부모들 에게는 이전 세대보다 다양한 부모역할이 요구된다고 인식하 고 있었다. 교육적 정보를 수집하고 의사결정을 해야 하며, 교 우관계에 관심을 가져야 하는 등 자녀의 학습 및 생활에서 부 모의 역할이 더욱 커졌다고 인식하고 있었지만, 주 양육자의 역할이 어머니에게 집중되어 이로 인해 느끼는 양육스트레스 를 경험하고 있었다.

차이점은 저희 엄마 아빠는 두 분 다 일을 하셨으니까 제가 스스 로 뮌가 정보를 찾아야 됐고, 그러다 보면 시간도 오래 걸리고 어 려윘고 그거를 어떻게 해야 되는지 방법을 잘 몰랐었어요. 근데 우리 아이 같은 경우에는 다양한 걸 알려주고 보여 주거든요. 이 중에서 네가 찾을 수 있을 거다. 찾아보자. 이런 식으로 '좀 더 엄 마 아빠보다 좀 더 가까이서 하고 있다라는 차이가 있는 것 같고. 그리고 저는 어렸을 때 엄마 일하고 계시니까 전 혼자서 뮌가 해 야 됐었죠. 밥이든 뮈든 생활을 혼자 했어야 됐는데 우리 아이는 그렇지 않다는 거? 그 차이인 것 같아요. (개별면접, ID 04, 2015년 12월 21일)

네. 부담감이 많이 돼있거든요. 그러니까. 어 저도 제가 자랄 때 는. 엄마가. 엄마라는 존재가 있긴 한데. 그래도 저한테 그렇게 많 이 영향을 끼쳤나 라는 생각이 많고. 저는 엄마 그런 모습을 보면 서. 그렇게 많이... 그렇게 엄마의 역할이 크다고는 생각을 안 했 
거든요. 그런데 지금은. 저.. 저만할 때는 저는 그냥 할머니가 계 셨지만. 할머니 할아버지가 계셨지만. 같이 자라지는 않았지만. 그래도 아 엄마가 없으면 할머니 집에 가서 있다가 오기도 하고. 제가 볼 때는. 저희 세대는 그나마 그래도 조부모랑 같이 자란 환 경이 많거든요. 그러다보니까. 그랬던 것 같아요. 지금은. 그렇게 엄마의 역할을 되게 중요시 하는 것도 지금은. 그때는 대가족 문 화여서 엄마가 아니어도 할아버지 있고, 할머니도 있고 그런데서 그 분들도 양육자 역할을 하셨고. 지금은 또 핵가족이고 아빠들 은 너무나 바빠서. 아빠들이 좀 주변을 보면. 그런. 아이들 양육에 되게 많이 발 벗고 나선 아바들도 많잖아요. 그런데 반면 저희 남 편은 정말 참여도가 저조한 남편이다 보니까. 저의 엄마의 역할 이 아주 커진. 정말 큰 부분인데. 그런 부분을 제가 너무... 부담스 러운 거죠. 엄마의... 네. (개별면접, ID 02, 2015년 12월 23일)

그들의 학령기에 부모들이 수행했던 역할보다 더욱 자녀에 게 밀착된 부모역할이 요구되고 있는 상황에서 학령기 자녀에 게 필요한 교육적 의사결정은 어머니에게 의존적이었으며 이 로 인해 어머니들은 양육스트레스를 경험하고 있었다. 과거에 는 생활에 바쁘고 부양해야 할 가족구성원이 많아 자녀들의 교육에 제한적으로 개입하였으나, 핵가족화와 출산율 저하로 가족의 구성원이 줄어들고 부모들의 교육열이 과열되면서 교 육에 대한 부모의 적극적인 개입이 요구되는 상황에서 어머니 가 느끼는 부담감은 갈수록 커지고 있다. 어머니가 느끼는 학 령기 자녀 양육 및 교육에 대한 스트레스는 본 연구에 참가한 전업주부와 취업모 대부분에게 공통적으로 발견되었다. 영유 아기만큼 일상생활에 대한 부모역할의 요구가 크지는 않지만, 여전히 돌봄이 필요할 뿐 아니라 학습지도가 필요한 학령 초 기 자녀에 대한 부모역할이 어머니에게 집중되면서 어머니들 은 이로 인한 피로감을 느끼고 있었다.

아침에도 일어나서 아이들을 챙기는 거는 제가 해야 하니까 더 일 찍 일어나서 일찍 애들 깨우고, 6 시 반 정도에 깨워서 밥 먹이고 부랴부랴 저도 준비해야 하니까 갔다가 또 애들 학교 끝나면 또 전화 오기 시작하거든요. 지금 어디 가고 있고. 그니까 일을 하면 서도 계속해서 아이들한테 신경을 써야 되고 또 퇴근하고 나서 아 프면 병원 데리고 가야하고 이게 다 제 일이니까. 그렇다고 남편 이 책임감 있게 같이 끼어들어서 해주는 것도 아니고 어쩌다가 정 안되면 부탁을 하는 거고 그 쪽에서 일이 없으면 해주는 거고 아 니면 나는 모르는 일이다... (개별면접, ID 09, 2015년 12월 19일)

아빠는 온전히 그냥 놀아라 이런 입장이고요. 교육에 대해서는
전혀 생각을 안 하고요. 혹시라도 조금 잘못하면 엄마 책임 이렇 게. 완전 너 때문이야 이건 아니지만. 자기가 터치 안하는 만큼 자 기 책임은 없는 거예요. (개별면접, ID 13, 2015년 12월 22일)

위에서 언급한 바와 같이 다양한 부모의 역할을 요구하는 현대사회에서 어머니들은 양육의 일차적 책임자로서 부모역 할이 자신에게 집중된다고 인식하면서 양육스트레스를 받고 있었다. 학령 초기 자녀의 부모역할과 자아실현 사이에서 갈 등하던 한 어머니는 결국 재택근무를 선택함으로써 부모역할 을 위해 자아실현 욕구를 유보하였으나, 일을 포기한 만큼의 보상이 양육을 통해 이루어지고 있지 않다고 인식하면서 이로 인한 심리적 갈등을 경험하고 있었다. 이와 같이 학령 초기 자 녀를 둔 어머니들의 부모역할 수행은 때로는 자아가 요구하는 욕구와 상충하면서 내적 갈등을 유발하고 있었고, 취업모의 경우에는 직장과 가정을 양립하는 데 어려운 시기를 보내고 있음을 알 수 있었다.

일단 아이 양육에 대한 그런 스트레스가 가장 크죠. 지금 뭐 어떻 게 보면 두 가지 아니 세 가지지. 아이 양육도 하지 엄마로서의 역 할도 하지 지금 뭐 집안에서 부인으로서 역할도 하는 것도. 또 어 떻게 보면 회사에서 직원으로서 역할까지 하고 있잖아요? 이게 다 잘할 수만은 없는데 지금 일단은 처음에 말씀 드렸다시피 재 택을 채택한 것도 아이 양육을 우선을 두고서 채택을 했잖아요. 제가 내 일을 포기할 만큼 어느 정도는 감수하고 할 만큼 이게 제 대로 안되니까 그거에 대한 스트레스가... (개별면접, ID 10, 2015 년 12월 19일)

\section{학령 초기 자녀를 둔 부모의 공동양육과 부부 관계}

자녀를 양육하면서 부모역할 수행과 부부관계는 상호관계가 있으며, 특히 학령기 자녀를 둔 부모의 역할 수행은 부부간 갈 등을 유발하는 매개체가 되기도 하였다. 본 연구에 참가한 어 머니들 중에서 배우자가 주중에 양육에 참여한다고 응답한 어머니들은 3 명이었고 이들은 모두 취업모였다. 대부분의 아 버지들은 주말에 놀이를 통해 양육에 참여하고 있었으며, 남 편의 바쁜 생활을 이해하기 때문에 현재 참여하는 수준에 만 족한다고 응답한 전업주부는 3 명이었다. 부모공동양육은 아 버지와 어머니가 동등한 자격을 가지고 자녀 양육에 대한 책 임을 지며, 함께 노력해가는 양육의 과정을 말한다(J. Park, 2015). 부모공동양육의 관점에서 유아기 자녀를 둔 아버지의 
자녀양육 참여에 관한 양적 연구(Yee, 2008)에 따르면, 직접적 돌봄, 양육적 역할, 그리고 자녀 교육 및 지도는 어머니 중심으 로 이루어지고, 실외놀이와 외출 등 활동 위주의 양육, 정서적 지지나 보호 등은 부모공동양육이 이루어진다고 보고하였으 며, 본 연구에 의하면 학령기에도 아버지의 역할은 활동 위주 의 양육에 집중되고 있음을 알 수 있었다.

평일엔 거의 시간 못 보내죠. 원래 사람도 좋아하고 술도 좋아하 는 사람이라. 그래도 저녁 때 들어오면... 하루 평균은 낼 수가 없 구요. 월요일부터 금요일까지 통틀어서 한 3-4시간. 근데 이제 3-4 시간인데 있었던 일을 애기한다기보다는 그 시간에 주로 셋 이 TV 시청을 하죠. 그런데 대신 주말에는 애 아빠가 활동적인 사 람이니까 많이 데리고 나가려고 그래요. 캠핑도 자주 가고 뮌가 공연이 있으면 같이 보기도 보러도 가고 그래요. (개별면접, $I D$ 03, 2015년 12월 18일)

요즘에 많이 하는 건 야구놀이. 집에서 일요일에 하루 정해놓고 아빠가 계속 공 던져주면 애들이 치고 점수 매기고요. 공기놀이 도 하고 날 좋을 때는 나가서 계속 인라인 타고, 배드민턴 치고 그 리고 저희 동네 놀이터가 흙 놀이터에요. 저 같은 경우에는 시간 이 나서 놀이터를 같이 나가면 벤치에만 앉아있고 "너네끼리 놀 아라” 거든요. 근데 계속 흙으로 같이 놀아주고 구름사다리를 도 전하기를 한다든가. 같이 놀아주는 스타일이에요. 학습적인 것은 많이 안 봐주고요. (개별면접, ID 17, 2015년 12월 23일)

이러한 관점에서 본 연구에 참가한 일부 어머니들은 부모 공동양육의 어려움과 이로 인한 양육스트레스에 대해 토로하 였다. 배우자의 아버지 역할에 불만족하다고 말한 연구참여자 들은 무심했던 배우자가 양육 및 교육과 관련된 의사결정의 결과에 대한 책임을 어머니에게 물을 때 부부간의 갈등이 발 생하게 되어, 지지적 부모공동양육의 어려움을 말하였다. ID 03 연구참여자는 어머니로서의 역할보다 배우자로서의 역할 을 우선하기를 바라는 남편과 자녀가 어릴 때는 부모역할이 우선이라는 자신의 의견 차이로 갈등이 있었다고 말했다. ID 02 연구참여자는 양육에 거의 참여하지 않는 남편에 대한 불 만을 토로하였으며, ID 13 연구참여자는 올바른 부모역할에 대한 관점에 차이가 있을 때 남편과의 관계에서 생기는 갈등 이 양육스트레스보다 더 크다고 인식하고 있었다. 이와 같이 학령 초기 자녀를 둔 부부들은 배우자로서의 역할과 학습이 시작되면서 역할 긴장이 가중되는 학령 초기 부모역할이 상충 하면서 부부갈등을 경험하고 있었다. 또한 배우자의 양육참여
가 충분하다고 인식하고 있는 일부 어머니들을 제외하고, 배 우자의 아버지 역할 수행에 대해 대부분의 어머니들은 불만족 하며 충분하지 않다고 인식하고 있었다. 실제로 양육참여는 주말 몇 시간의 놀이를 통해 이루어지는 경우가 대부분이었으 며, 어머니와 공동양육을 하고 있는 아버지는 소수에 불과하 였다.

애 아빠는 에너지가 많고 활동적인 사람이라 저랑 많이 힘들었던 거죠. 저는 모든 에너지를 아이한테만 우선은 쏟고 아이가 커지 면 그 때 신랑하고 보내야 된다고 생각을 했고 신랑은 젊을 때 결 혼해서 젊어서 좋을 때 부인하고 같이 뭐든지 해야 된다고 생각 을 했었던 사람이죠. (개별면접, ID 03, 2015년 12월 18일)

외출을 하려고 챙기다 보면 남편은 도와주지를 않아요. 어디 같 이 외출하는 거는 돌잔치, 결혼식, 뭐 이런 거 밖에 거의 없었어 요. 워낙 바쁘다보니까 같이 주말에 아이들을 데리고 어디 가는 건 거의 없었어요. 제가... 가더라도 제가 데리고 가고. (개별면접, ID 02, 2015년 12월 23일)

놀아주는 건 잘 놀아줘요. 제 의견이 없어요. 그냥 몸으로 놀아주 고 하는 거 본인이 놀아주고 싶어서 할 때. 예를 들면 핸드폰 게임 을 해요. 아이들 앞에서만 하지 말아라. 본인 스트레스 해소 하는 건 좋은데 애들 앞에서만 하지 말아라. 어느 날 그러는 거예요. 내 가 하고 싶어서 내가 하는데. 그런 입장이에요. 애들 앞에서 술 먹 지 말아라. 술은 먹는 거다 음식이다 막 이렇게 하면서. 아무리 대 화를 해도. 저는 분명히 애기를 했어요. 그건 안돼 애기를 했는데 여기서 여기에서 해 이렇게 애기를 해버리니까 그런 부분이 부딪 힐 때가 많아요. 그 부분에 대해서는 애기를 하죠. 깊이 애기를 할 수는 없어요. 워낙 대화를 안 하는 사람이기 때문에. 애들한테 애 기를 해요. 그 때는 막 이렇게 싸울 수는 없으니까 지난 다음에 엄 마의 생각이 이랬기 때문에 안 된다고 했는데 아빠가 된다고 했 지만 그건 좀 달랐던 부분이라고 애기해줘요. 많이 힘들어요. 애 들 보는 거보다 이게 더 힘들어요, 지금. (개별면접, $I D$ 13, 2015년 12월 22일)

\section{학령 초기 자녀에 대한 양육행동의 혼재}

본 연구에 참가한 어머니들 중에서 8 명은 자신의 양육행동 유 형을 민주적(3명), 권위주의적(4명), 혹은 허용적(1명) 유형으 로 구분하였고, 나머지 11 명의 어머니들은 자신들의 양육행 동이 하나의 유형으로 분류될 수 없으며 일관되지 않다고 이 
야기하였다. ID 12 연구참여자는 상황에 따라 학령 초기 자녀 를 대하는 양육행동이 달라진다고 말하였으며, ID 16 연구참 여자는 자신의 양육행동이 민주적인 듯 보이지만 본질적으로 자녀의 의견을 존중하기 보다는 권위주의적이라고 인식하고 있었다.

민주적인 방법도 쓰려고 하다가. 강압적인 방법도 쓰고. 단호하 게도 했다가. 달래기도 했다가. 일관성이 떨어지나요, 좀? (개별면 접, ID 12, 2015년 12월 21일)

권위주의적인 거요. 굉장히 민주적인 척 하면서 권위주의적인 사 람이에요 제가. 애들한테 민주적인 척 하면서 내가 하고 싶은 대 로 애들을 끌고 가요. 결국은 권위적이더라고요. 저는 민주적으 로 키운다고 생각했는데 결국엔 내 마음대로 하고 있어요. (개별 면접, ID 16, 2015년 29일)

특히 학령기에 진입하면서 본격적으로 학습이 이루어져야 한다고 생각하는 일부 어머니들은 자녀와의 관계에서 학습으 로 인한 갈등을 경험하고 있었으며, 학습과 관련해서는 평상 시와 달리 통제적이고 권위주의적인 행동을 나타내고 있었다. 대부분의 연구참여자들처럼 ID 10 연구참여자는 자녀들이 방과 후에 가정에 돌아오면 놀이 전에 어머니 스스로 정해놓 은 학습량을 숙제처럼 하도록 학습지도를 하고 있었다. 그러 나 자녀가 자신의 계획대로 하지 않을 때 자녀와의 갈등상황 이 발생한다고 말하였다. 또한 ID 07 연구참여자는 대부분의 경우에 자녀에게 허용적이지만 학습에 있어서는 평상시와 달 리 강압적인 모습을 보이게 된다고 이야기하였고, 자녀가 초 등학교에 입학하기 전에는 자녀와의 갈등이 없었다고 하였다. 본 연구에 참가한 대부분의 어머니들은 자율성을 기초로 자기 주도 학습이 이루어져야 한다고 인식하고 있었지만, 실제적인 학습지도에 있어서는 자녀의 학습량을 정하고, 매일의 학습량 을 확인하며 계획대로 자녀의 학습이 이루어지지 않으면 자녀 와의 관계에서 갈등을 경험하고 있었다.

학습적인 부분... 그러니까는 늘 할 일이 정해져 있거든요. 항상 하루하루 해야 할 일이 정해져 있고, 양이 정해져 있는데 그거를 저는 좀 네가 놀더라도 이거를 다 해놓고 맘 편히 놀아라 주의인 데 아이는 그냥그 시간을 즐기고 싶은 거예요. 그니까는 그거에 따라서 우리 엄마는 나는 왜 맨날 안 돼? 놀면 왜 맨날 안 돼? 이 런 식으로 나오는 거죠 그러면 이제 또 다시 또 그 애기를 해야 돼 요. 너는 이거를 해야 되고 네가 지금 나갔다가 들어오며 이걸 하
겠니? 졸린다고 자겠지 아니래요 자기는 안 그런대요. 그런데 너 이때까지 네가 해왔던 행동을 보면 넌 항상 그랬어. 제가 항상 그 렇게 이야기해요. 그래서 아이의 의견을 들어주기보다는 늘 저의 플랜대로 움직이길 바라는 거죠. (개별면접, ID 10, 2015년 12월 19일)

저희 아이도 영화 보는 걸 좋아하더라고요. 그래서 영화 보고 싶 다면 그러면, 웬만큼 하고 싶다고 그러면 다 해줘요. 뭐든지. "엄 마 어디 가고 싶어." 그러면 가던 길에 하고 "뮈가 먹고 싶어." 그 러면 다 해주고. 공부하는 면 빼고는. (중략) 너무 화가 나면 얼마 전에는, 밖에다가 책가방하고 책하고 싹 다 버렸어요. 저희 애보 고 나가라고. 그런데 자기를 내쫓지만 말아달라고 그러더라고요. 그럼 다른 애들은 나가서 책하고 가방을 주어왔을 텐데 저희 아 이는 주어오지를 않더라고요. 자기만 내쫓지 말아 달라 그래요. (개별면접, ID 07, 2015년 12월 22일)

본 연구에 참가한 어머니들은 학령기 자녀가 자율적으로 일상생활과 학습을 수행하고, 독립적인 성인으로 양육하는 것 을 부모역할의 궁극적인 목적으로 생각하고 있었다. 이를 위 하여 학령 초기에 학습 뿐 아니라 생활에서도 자율성을 증진 시키기 위하여 노력하고 있었다. 유아기에서 학령기로 전환하 면서 과도기에 있는 학령 초기에 스스로 해나가는 습관을 형 성하기 위하여 노력하고 있었으나, 단시간에 생활습관이 독립 적으로 이루어지는 것이 아니어서 인내심을 가지고 자율적 습 관을 형성하기 위하여 노력하고 있었다.

우선 엄마가 챙겨줄 수가 없잖아요. 학교에 있는 동안에는. 그래 서 자립심이라고 해야 될까. 그거 하는 데도 되게 시간이 많이 걸 리더라고요 (개별면접, ID 13, 2015년 12월 22일)

기본적으로 자기가 해야 된다고 생각을 해요. 그리고 준비물이라 든지 학교 숙제라든지 그런 거는 다 해야 된다고 생각해요. 기본 적으로 학교는 늦으면 '지각했네.' 하고 뛰어가야 된다는 거. '늦으 면 늦을 수도 있지.'가 아니고 '오늘 학교에서 뮐 준비하라고 했는 데 내가 못했어. 좀 일찍 가야겠어.' 이런 마음가짐? 이런 건 자기 네들이 있어야 된다고 생각을 해요. (개별면접, ID 19, 2015년 12 월 23일)

그러나 그 과정에서 자율적인 습관을 형성하기 위하여 어 떻게 도와줘야 하는지 혼란을 느끼며, 일관된 양육행동을 하 고 있지 못하는 것을 자책하고 있는 것으로 보였다. ID 03 연 
구참여자는 이러한 혼란 때문에 느끼는 양육스트레스가 있었 고, ID 09 연구참여자는 학습지도와 관련한 자신의 일관성 없 는 양육행동에 대해 이야기하였다. 이와 같이 학령 초기 자녀 를 둔 어머니들은 자녀의 학습 및 생활지도에서 유아기와는 다른 양육행동의 변화를 경험하고 있었다.

네, 그래서 어느 정도까지가 맞는 건지. 제 스스로 생각했을 때 정 말 아이들이 '이제는 엄마의 도움이 필요 없어'라는 걸 엄마가 느 낄 때까지 엄마가 도와줘야 되는 건지. 그런 부분이 좀 힘들어요. 그런 기본적인 것들은 본인이 해야 된다고 생각하지만. (개별면 접, ID 03, 2015년 12월 18일)

그런데 그걸 다급할 때까지 놔두는 것이 맞는 건지 그 다음날 학 교 끝나고 학원 가기 전까지 한두 시간 비면 그때 숙제를 하는 거 예요. 미루고 미루고 미루다가 그래서 그때 가끔 생각나는 게 안 하고 그냥 혼나 보기도 해야 한다고 해서... 뒸다가 어쩔 때는 뭐 라고 했다가... (개별면접, ID 09, 2015년 12월 19일)

\section{부모로서 느끼는 감정의 스펙트럼}

\section{부모로서의 원초적 기쁨}

본 연구에 참가한 어머니들이 부모로서 느끼는 기쁨은 자녀와 의 신체적 접촉과 즐거운 대화에서 오는 일상적 경험으로부터 생성되었다. 학령 초기 자녀들과의 관계에서 느끼는 정서적 만족감은 존재 자체로 느껴지는 충족감과 영유아기 자녀와의 관계처럼 안아주고 이야기 나누는 일상적인 것에서 느껴지는 것이다. ID 01 연구참여자와 ID 17 연구참여자는 자녀들의 존 재만으로 정서적으로 편안함을 느끼고 있었으며, 어머니들은 자녀의 긍정적 정서를 공유하면서 기쁨을 느끼고 있었다.

그러니까 애들은 어른들과는 다르게 진짜 금방 또 싸우다가도 되 돌아서면 엄마 사랑해 하고 한 번 안아주면 또 풀리고, 그런 게 되 게 기본적인 인간의 모습 같아요. (중략) 애들은 그낭 한 번 안아 주고, 꼭 안아주면 그걸로 끝인 거예요. 그러니까 그런 것들이 되 게 좋기도 하고 나도 좋고. 그러니까 누군가를 이렇게 꼭 안아준 다는... 항상 안고 있잖아요. 신체적으로 그런 걸 항상, 이게 넷이 다 보니까 어디에든 이렇게, 육체적으로도 힐링이 되니까. 물론 힘들기도 하지만... 그런데 진짜 힘들 때는 애 안고 자는 게, 자면 은 다 풀리기도 하고 더 잠이 잘 오고. 그러니까 그런 면들도 되게 중요한 거 같아요. (개별면접, ID 01, 2015년 12월 17일)
와서 애기를 해요. 자기가 뮈했다. 되게 신나서 애기를 하거든요 애가. 그런 거 보면 그때 행복한 것 같아요. 자기가 즐거워서 기뻐 서 애기할 때? 그럴 때 '그래 크고 있구나.'라는 생각이 들 때. (개 별면접, ID 04, 2015년 12월 21일)

제가 불면증이 있거든요. 잠 안 오면 애들 옆에 가면 그나마 편해 요. 그래도 좀 수면상태랑 아닌 상태를 왔다 갔다 하기는 해도. 그 래도 편한 상태로 있거든요. 그릴 때 '아, 애들이 되게 나를 편하 게 해주는 존재구나.' 하는 거 하고요. 또 애들하고 간식 같은 거 밥 먹으면서 애기 주고받고, 재잘재잘거릴 때. (개별면접, $I D 17$, 2015년 12월 23일)

\section{우울감의 원인이 되는 경제력}

본 연구에 참가한 학령 초기 자녀를 둔 어머니들은 자녀양육 에 있어서 경제적 여건이 중요하다고 인식하고 있었으며, 특 히 교육비가 증가하는 학령기에 필요한 교육을 위해 원하는 만큼의 경제적 지원이 이루어지고 있지 않다고 인식할 때 이 에 대한 스트레스와 좌절감을 경험하고 있었다. 특히 학군 등 의 물리적 교육환경 뿐 아니라 사교육 제공 등에 대한 압박감 을 느끼는 일부 어머니들은 스트레스를 높이 지각하고 우울감 을 느끼고 있었다. ID 01 연구참여자는 부모로서 자녀가 원하 는 만큼의 경제적 지원을 해줄 수 없을 때 부모역할의 스트레 스를 가장 크게 느끼고 있었으며, ID 02 연구참여자는 가정의 어려운 경제적 여건으로 인해 부모역할에 대한 만족감을 느낄 수 없다고 말하였다. 이러한 경제적 여건으로 인한 부모역할 스트레스는 ID 02 의 연구참여자가 우울감을 느끼게 하는 원 인이 되고 있었다.

그 중에서는 스트레스는 이제... 그렇죠. 애들한테 해주지 못하는 거? 애들 되게 이렇게 해주면 좋을 것 같은데 애들이 많다보니까 다 해주지 못하는 부모 심정? 네. (개별면접, ID 01, 2015년 12월 17일)

저도 그런 경제적인 도움을 주고 싶은데. 저도 너무나 지쳐있어 서 이게 회복이 안 되는 거예요. 오늘도 남편이 또 그랬어요. 도대 체 집에서 뮐 하고 있는지 모르겠다고. 자기는 이렇게 힘든데. 경 제적으로 좀 도움을 주고 그랬으면 하는데. 그것도 안 되고. 제대 로 또. 집안... 살림이나 이렇게 보면 또 제대로 안 되어있고 그러 거든요. 그냥 아이들 보내고 그냥 오전이. 그냥 멍하게 있게 돼요. (하다못해) $T V$ 를 보거나 뭐 그러면. $T V$ 도 안보고. 그냥 일은 손에 
또 안 잡히고. 그게 몇 년 째 그렇게 된 것 같아요. (개별면접, $I D$ 02, 2015년 12월 23일)

\section{부모로서의 양육신념과 양육행동의 괴리에서 오는 자책}

본 연구에 참가한 어머니들은 학령 초기 자녀를 위한 양육행 동이 자신들이 생각하는 좋은 부모역할에서 벗어날 때 이에 대한 죄책감을 느끼고 있었다. ID 15 연구참여자는 자녀를 훈 육하면서 경험하는 죄책감에 대해 이야기하였으며, ID 10 연 구참여자는 자신의 양육행동이 부모로서의 양육신념과 다를 때 느끼는 부정적 정서에 대해 말하였다. 다시 말하면, 부모의 신념과 양육행동 간의 차이를 느낄 때 부모의 양육효능감은 저하되는 것으로 보였으며, 이러한 양육효능감의 저하는 외부 의 평가에 의해서 영향을 받는 것으로 보인다. ID 18 연구참여 자는 외부에서 자신의 자녀에 대한 긍정적인 평가를 듣게 될 때 자신의 양육효능감이 높아진다고 인식하고 있었다. 이와 같이, 대체로 학령 초기 자녀를 둔 어머니들은 자신의 양육행 동에 대한 자기 확신이 부족하고, 자녀에 대한 자신의 주관적 인 평가보다는 외부에서 보이는 자녀에 대한 평가를 민감하게 인식하고 있었다.

말을 하다가 조금 아이 입장에서 더 생각을 해줘야 되는데 말하 다가 몇 번 해서 못 알아들으면 욱해요 제가. 그래서 소리를 지르 게 되요. 그러다가 매까지 들어요. 근데 이제 혼내고 나서 나중에 '아 내가 정말 잘 혼냈어. 너를 위해 잘 혼냈어.' 이런 마음을 가졌 으면 잘 혼내는 건데 후회스러울 때가 있어요. 그러면 그거는 제 가 화풀이. 육아 힘든 거를, 둘째한테 힘든 거를 스트레스를 푸는 거 밖에 안 되잖아요. 그렇게 하면 안 되죠. 미안하죠. (개별면접, ID 15, 2015년 12월 21일)

노력은 많이 하는데 이거 너무 실천이 안 되니까 항상 이론과 행 동이 따로 노니까. 그게 어떻게 보면 참 속상해요. 아는 만큼 실천 이 안 되니까 아이를 키우는데 '이렇게 키워서 되겠나...' 이런 생 각도 있고 '재를 이렇게 키워서 재를 뭐를 만들려고 그러지?' 뭐 이런 생각도 들 때도 있고. 그니까는 딱 정해진 답이 있으면 그거 대로 그 지침대로 이렇게 이렇게 가면 되는데 그런 게 없다 보니 까 좀 나 자신이 어떤 틀을 딱 세워서 이렇게 이렇게 가야... 개척 을 해나가야 되니까 그게 너무 힘든 것 같아요. (개별면접, ID 10 , 2015년 12월 19일)
그래도 남들한테 남들이 우리 아이를 애기를 했을 때 "괜찮은 아 이야."라고 저한테 애기를 해짔을 때. "오 너희 아이 생각보다 그 렇지 않아. 애 뜰들해. 잘 키웠어.” 이런 애기를 들었을 때 아 내가 잘못 키우진 않구나. 그런 생각이 드는 것 같아요. (개별면접, ID 18, 2015년 12월 23일)

\section{정답이 없는 양육에 대한 불안감}

자녀양육은 그 결과가 즉각적으로 나타나지 않는다는 점에서 어머니들로 하여금 불안감을 느끼게 하고 있었다. 즉, 어머니 들은 장기적인 관점에서 부모역할을 잘하고 있는 것인지 확신 할 수 없다고 인식하고 있었으며, 자신의 부모역할에 대한 구 체적 지침을 필요로 하고 있었다. ID 04 연구참여자는 학습과 관련해서 자녀의 의견을 존중하고자 노력하지만 부모로서 얼 마나 개입해야 하는지 혼란스러워 하고 있었으며, 선택의 결 과에 대해 막연한 불안감을 토로하였다. ID 10 연구참여자는 올바른 양육은 정답이 없으며, 아동의 성향 및 환경에 따라 적 절한 선택을 하는 것으로 인식하고 있었다. 그러나 이러한 선 택의 결과가 자녀에게 악영향을 미칠 수도 있다는 불안감을 느끼고 있었다.

그랬더니 아이가 학습이 재미로 다가가기보다 해야 되는 일이라 고 받아들이는 것 같더라고요. 그래서 이제 시작인데 되게 무서 운 거예요. 그러면 안 되겠다 싶어서 2학년이 되고 나서는 정말 다 놓구요. 아이한테 선택을 하게 짔어요. "네가 '진짜로 해야겠 다.'라고 생각이 드는 것만 하자.” 그랬더니 본인이 선택을 하더라 구요. "대신 네가 선택을 했으니까 이거에 대해서는 니가 약속한 거에 대해선 책임을 져라.” 이건 좀 생활적인 거랑 연결이 되는 거 예요. "약속을 했고 니가 하겠다고 마음을 먹었으면 끝까지 해." 이건 생활적인 거랑 연결이 되기 때문에. 그렇게 되니까 아이도 본인이 한 말이 있고 그거에 책임을 지려고 노력을 하더라구요. 그래서 저는 좀 선택권도 주면서 놀게도 하면서 그런 게 아닌가 싶어요. (중략) 불안은 있죠. 내가 잘 하고 있는 건지. 항상 '아이한 테 선택권을 준다.'라고 하지만 잘못된 선택을 할 수도 있는 거고 그거를 내가 그렇지 않을 정도로 조금 내 의견을, 내 생각을 주입 해 주는 게 애한테 좋은 걸까라는 의구심? 아직 다 크고 본인이 본 인 삶을 영위하지 않은 상태이기 때문에 그게 잘 되고 있을 건지 에 대한 약간 불안함은 있어요. 그건 나중에 시간이 지나고 알 수 있을 거기 때문에... (개별면접, ID 04, 2015년 12월 21일)

내가 맞게 키우는 건지를 모르니까. 애를 양육하는 이 상황이 방 
법이 맞는지를 그니까 이 양육은 답이 없잖아요. 어떻게 보면 아 이 성향도 다 틀리고 집안 환경도 그렇고 다 틀리기 때문에 답은 없는데 그래도 어느 정도의 틀 안에서 제가 잘 하고 있는지 그걸 잘 모르겠어요. 그걸 잘 모르니까 '어... 애한테 내가 이렇게 했을 때 악영향을 끼치지 않을까?' 하는 생각도 들고 너무 애를 애의 의 견만 들어줘서 너무 자기만 아는 아이가 되지 않을까 하는 걱정 도 있고 그래서 진짜 이게 맞는지 틀리는지도 잘 모르겠어요. (개 별면접, ID 10, 2015년 12월 19일)

\section{논의 및 결론}

본 연구는 학령초기 자녀를 둔 어머니들을 대상으로 부모됨 경험에 관한 그들의 생각을 인지.행동.정서적 측면에서 심층 적으로 살펴보았다. 부모됨 경험의 인지.행동.정서적 측면은 각각 양육신념, 양육행동 및 양육 시 경험하는 긍정적, 부정적 정서를 의미한다. 본 연구의 결과를 토대로 논의하고 결론을 내리면 다음과 같다.

첫째, 본 연구에 참가한 어머니들은 독립적인 인격체로 성 장해 가는 학령 초기 자녀를 위해 가장 중요한 부모역할을 성 장의 조력자로서 인식하였다. 즉, 부모는 자녀가 원하는 길을 갈 수 있도록 그리고 바람직하게 성장할 수 있도록 자녀의 입 장에서 바라보고 지지해 주는 역할을 해야 한다고 인식하였 다. 더불어, 자녀가 부모와 함께 평생을 살아갈 수 없기에 이 들이 독립적으로 살아갈 수 있도록 자녀의 자율성과 주도성 을 키워줄 필요성을 크게 느끼고 있었다. 이러한 결과는 학령 기 전환기에 있는 어머니들이 자녀를 믿고 지지해 주는 지원 자적인 부모역할이 중요하다고 보고한 연구들(Chung, Chung, Kim, \& Park, 2007; S. J. Kim et al., 2015)과 일치한다. 자녀가 학령기로 접어들면서 학교에서의 생활이나 또래관계와 관련 해서, 어머니들은 자녀의 생활 및 학습습관이나 적응이 단기 간에 이루어지지 않는다는 것을 인식하였고, 이를 위해서는 부모 스스로가 인내심을 가지고 기다려줄 필요가 있음을 지각 하였다. 그러나 긍정적인 부모역할에 대한 인식과는 달리 실 제적인 양육에서는 상반되는 부모역할을 수행하면서 생기는 스트레스가 발생할 수 있다는 점을 고려해 볼 때(S. J. Kim et al., 2015), 부모가 인식하는 성장의 조력자로서의 역할을 적절 히 수행하기 위해서는 부모교육을 통해 아동의 발달단계 특성 에 적합한 구체적 양육기술을 포함한 부모역할을 학습해야 할 것이다. 더불어, 학령기 자녀가 자율성이나 책임감을 발휘할 수 있도록 자녀의 의사결정을 존중하고 신뢰하기 위한 노력이
필요하며, 학령 초기 자녀를 둔 부모들 간의 자조모임을 통해 바람직한 양육관을 확립하기 위한 상호지지와 노력이 필요해 보인다.

둘째, 본 연구에 참가한 어머니들은 자녀양육, 특히 학교생 활과 관련한 부모의 선택과 역할이 자신의 부모세대보다 더 커졌다고 지각하였다. 그들의 부모세대는 생활에 바빠서 자녀 를 양육하고 교육하는 일보다 아버지는 경제적인 활동에, 어 머니는 대가족을 부양하는 역할을 수행하였다. 따라서 어머 니들은 어린 시절에 학교생활과 관련하여 부모에게 의존하기 보다 스스로 선택하고 결정해야 하는 독립적인 특성이 강했 다고 회고하였다. 그러나 그들이 부모세대가 된 현재는 자녀 의 교육이나 학교생활 및 교우관계 등에서 부모들이 결정해 야 할 일이 많다고 생각하며, 특히 학습지도와 관련한 영역에 서의 부모역할이 어머니에게 집중되면서 양육스트레스를 많 이 경험하였다. 이는 초등학생 자녀를 둔 부모들이 자녀의 학 업성취에 관한 측면에서 불안감이 높다는 연구결과들(Huh, 2014; Chi, 2010)과 유사하다. 본 연구결과는 부모로부터 받은 양육이 자녀에게로 세대 간 전이된다는 연구결과들(S.-Y. Park, Doh, Kim, \& Song, 2014; Song et al., 2014; Simons et al., 1991) 과 다소 상이하다는 점에서 흥미롭다. 다시 말하면, 본 연구에 참가한 어머니들의 부모세대는 자녀교육에 비해 경제 활동이 나 가족부양 역할에 더 초점을 두었던 반면, 현대 부모세대는 자녀의 학교생활이나 학습에 대한 역할이 커졌다는 점에서 양 육에 대한 역할이 그대로 전이되지 않고 상반된 모습을 보여 자녀양육의 세대 간 전이가 이루어지지 않고 있었다. 이러한 모습은 시대적, 상황적 변화 측면에서 충분히 해석할 만하다. 핵가족화나 자녀수의 감소는 부모로 하여금 자녀양육의 책임 을 더욱 가중시키고, 특히 주변 부모들이나 언론매체를 통한 사회적 분위기가 현대의 부모역할 모습에 영향을 미칠 수도 있을 것이다. 역설적으로, 부모세대로부터 모델링이 되지 못 한 상태에서 현 사회적 흐름에 따른 자녀의 학교생활이나 학 습적인 측면에 대한 과중한 의사결정은 어머니들에게 불안감 이나 스트레스를 가중시킨 것으로 보인다. 따라서 자녀의 학 령기 전환에 따른 부모의 새로운 역할 수행과 이에 대한 스트 레스를 완화하기 위한 노력이 필요해 보인다.

또한, 학령초기는 유아기에서 학령기로의 전환기로 환경 의 변화에 따른 부모의 역할이 더욱 필요하며(S. J. Kim et al., 2015), 부모들은 아동의 학교적응을 위해 이 시기에 자녀양육 에 더욱 집중하게 된다. 본 연구에 참가했던 어머니들 중에는 부모역할과 자아실현 사이에서 느끼는 갈등으로 인해 재택근 무를 선택하여 자녀양육에 집중하고자 하였으나, 일을 포기한 
만큼의 보상이 양육을 통해 이루어지고 있지 않다고 인식하면 서 심리적 갈등을 경험하는 경우도 있었다. 이는 취업모가 전 업주부보다 부모역할에 대한 만족도가 높게 나타난 연구결과 (Goldsteen \& Ross, 1989)나 취업모의 양육스트레스가 더 낮게 나타난 연구결과들(Sohn, 2012; Um \& Yang, 2011)과 유사하 게, 직장 동료들 간에 비공식적인 우정이나 관계 형성은 자녀 양육에 대한 조언을 얻을 수 있는 좋은 기회가 되며, 때로는 가 정에서 자녀만 바라보던 환경에서 다소 벗어날 수 있다는 점 에서 직장은 정서적 지지체계가 될 수 있다. 따라서 직장이 아 니더라도 전환된 역할에 맞는 어머니 역할을 함께 공유하고 지원할 수 있는 프로그램이나 지지체계가 필요해 보인다. 이 와 동시에, 바람직한 부모역할은 어머니 자신의 성인기 발달 을 긍정적으로 이끌 수 있다는 점(Doh, 2012; J. S. Lee, 2003)에 서 부모로 하여금 부모역할이 가지는 의미가 얼마나 큰지를 인식할 수 있는 기회가 제공되어야 할 것이다. 자녀와 더 많은 시간을 질적으로 함께 할 수 있는 경험이 이후 자녀의 건강한 발달을 위해 얼마나 소중한 기회가 되는지를 이해하고, 현재 어머니 자신의 역할에 대한 심리적인 만족감을 높이기 위한 다양한 노력이 필요하리라 사료된다.

셋째, 어머니들은 자녀를 양육하는 과정에서 부모공동양육 이나 부부관계 등 배우자와의 관계에 있어 다양한 경험을 보 고하였다. 부모공동양육은 부부가 자녀양육에 대해 지속적으 로 대화를 나누며 서로 일치하는 방법으로 자녀를 함께 양육 하는 것으로, 자녀에게 안정감을 주고 궁극적으로 자녀의 긍 정적 발달을 돕는다(Doh, 2012). 이러한 점에서 자녀가 학령 기가 되면서 부모로서의 역할이 가중되었음에도 불구하고 상 대적으로 배우자의 역할이 충분하지 못하거나 부모공동양육 이 이루어지지 않을 때, 이는 부부갈등이나 어머니의 양육스 트레스로 연결되는 것으로 보였다. 또한, 어머니의 관심이 자 녀에게로 치우치다보면 배우자로서의 역할에 소홀하게 되어, 이 또한 배우자와의 갈등을 경험하기도 하였다. 이는 자녀가 학령기가 되면서 어머니들이 자녀양육과 관련하여 우선적으 로 협조하고 의논해야 할 배우자와의 관계에서 부모공동양육 이 이루어지지 않아 스트레스를 경험한다는 연구결과들(S. J. Kim et al., 2015; K. H. Kim \& Cho, 2000)과 일치한다. 본 연구 의 참가자들 중에는 배우자가 바쁜 일과에도 불구하고 주중 저녁이나 주말을 이용하여 남편으로서, 아버지로서의 역할을 잘 수행해 주는 경우도 있었으나, 부모역할의 대부분을 어머 니가 전적으로 하는 경우에는 부부갈등을 경험하는 것으로 나 타났다. 이는 아버지 역할에 대한 인식이나 태도는 변화되었 지만 양육 참여와 같은 행동적 측면에서의 변화는 미비하다는
연구결과(J.-H. Kim, 2005)나 아버지들의 실제 역할 수행이 그 들의 역할 인식보다 낮다는 연구결과들(S.-E. Choi, 2009; Han $\& \mathrm{Kim}, 2007)$ 을 통해서도 알 수 있다. 특히, 어머니의 양육스 트레스 감소에 배우자의 지지가 중요하다는 연구결과들(Jun \& Park, 1996; Keum \& Kim, 2014; S. M. Kim, 2004)이나 자녀 의 건강한 발달을 위해서는 부모공동양육이나 아버지의 역할 이 매우 중요하며, 어머니의 긍정적 양육을 이끌어내기 위해 서도 배우자의 지지가 중요하다는 연구결과(Doh, 2012)와도 맥을 같이 한다. 즉, 학령기로의 전환 과정에서 어머니의 양육 스트레스를 줄이고 바람직한 양육을 위해서는 배우자의 지지 와 더불어 건강한 부부관계가 중요하며, 부모공동양육을 실천 하기 위한 다양한 교육적 지원과 아버지를 대상으로 한 부모 교육이나 가족지원 프로그램이 필요해 보인다.

넷째, 어머니들은 학령 초기 자녀를 양육하면서 상황에 따 라 양육행동의 혼재를 경험하는 경향이 있었다. 어머니들은 민주적 양육을 한다고 답하는 경우도 있었지만, 과반수의 어 머니들은 상황에 따라 일관되지 못한 양육을 하는 것으로 보 고하였다. 어머니들은 자녀의 학령기 진입과 동시에 학습량이 늘어나면서 자녀와의 관계에서 갈등을 경험하는 것으로 보였 다. 이는 자녀가 학령기가 되면서 경험하는 학업에서의 변화 로 인해 부모-자녀관계에서의 갈등을 유발할 수 있다는 연구 결과(Nomaguchi, 2012)나 자녀가 학령기가 되면서 부모로서 다양한 역할 긴장과 스트레스를 경험할 수 있다는 연구결과들 (Ha \& Jang, 2010; S. J. Kim et al., 2015)과 일치한다. 즉, 학업 보다는 부모와의 사회적 경험을 통해 정서적 지지와 안정감을 갖기를 원하는 자녀와 학업의 중요성을 강조하는 부모 사이에 서 갈등상황이 발생할 수 있다. 부모와의 관계에서 학업수행 에 대한 부담과 걱정이 아동의 심리적 어려움을 가중시킨다는 연구결과들(Kee, Shin, \& Hong, 2009; J.-A. Lee \& Chung, 2012; Y.-O. Lee \& Lee, 2011)을 통해서도 부모-자녀 간 갈등을 예측 해 볼 수 있다. 특히, 어머니들이 자녀와의 관계에서 평소에는 허용적이지만 자녀의 학습과 관련해서는 강압적이라는 점에 서 스스로 비일관되게 양육한다고 지각한 점은 매우 흥미롭 다. 이는 최근 언론에 나타난 기사와도 유사한 것으로 교육열 이 높은 한국 부모들은 자녀에게 생활습관에 있어서는 자율성 을 부여하면서도 교육은 통제하는 면이 있어서 아동들이 행복 감을 느끼기가 어려워 보인다(S. Y. Kim \& Noh, 2016). 즉, 유 아기에 비해 학업이 강조되는 학령기에 진입하면서 부모들은 자녀의 교육에 대해 더욱 관심을 갖게 되고, 이는 통제적인 양 육으로도 이어지는 것으로 생각된다.

자녀의 학업에 있어 부모의 생각이나 경험을 강요하는 것 
이 자녀의 이후 발달에 도움이 된다고 생각하는 부모와 부모 의 기대에 도달하지 못함으로 인해 경험하는 자녀의 좌절감 이 상충할 때, 부모와 자녀 모두 스트레스를 경험하기 쉽다. 자 녀와의 관계에서 어머니 자신의 정서가 편안하지 않을 때 권 위주의적인 양육으로 이어질 수 있으며(Abidin, 1990; Jun \& Park, 1996), 어머니의 심리적 건강이 자녀의 발달에 영향을 미 친다는 점(Barry, Dunlap, Lochman, \& Wells, 2009; J.-H. Kim, Doh, Shin, \& Kim, 2011)에서, 자녀와의 관계에서 경험하는 부 모 자신의 갈등을 조절할 수 있는 정서조절능력이나 감정완화 기술에도 관심을 가질 필요가 있을 것이다. 특히, 본 연구 참가 자들의 대부분이 자녀가 학령기가 되면서 경험하는 갈등의 주 요인으로 학습을 꼽았고, 자녀의 자기주도적인 학습이나 올바 른 학습습관과 관련한 지도방법을 알지 못해서 더욱 혼란감을 경험하는 것으로 보고하였다. 따라서 학령기 자녀를 둔 부모 에게는 자녀의 학습지도에 대한 올바른 양육정보를 제공하는 것이 매우 중요해 보인다.

마지막으로, 본 연구에 참가한 어머니들은 자녀와의 관계 에서 기쁨, 우울, 자책 등 다양한 감정의 스펙트럼을 경험하였 다. 구체적으로는 자녀를 양육하면서 느끼는 기쁨과 정서적 인 충족감과 같은 긍정적 정서와 더불어, 양육에 드는 경제적 인 비용에서의 어려움이나 부모의 신념과 양육행동의 괴리에 서 오는 자책감, 정답이 없는 부모역할에서 오는 불안감과 같 은 부정적 정서를 경험하고 있었다. 이는 부모들이 부모역할 을 수행하는 과정에서 기쁨, 좌절, 두려움 등의 다양한 정서를 경험할 수 있다는 연구결과(Bornstein, 2002)와 일치한다. 어머 니들은 부모됨 경험자체가 삶의 원천적 기쁨을 제공한다고 보 고하였는데, 이는 부모인 성인이 그렇지 않은 성인에 비해 행 복감이 높다는 연구결과(Nelson et al., 2013)나 장애 자녀와 함 께 한 경험의 결과로 삶의 의미가 풍부해졌음을 느낀 연구결 과(H.-J. Kim \& Jung, 2014)와도 그 맥을 같이 한다. 다시 말하 면, 부모됨 경험이 성인기 발달과업에 부합한다는 면(Erikson, 1963)에서도 이해해 볼 수 있다. 그러나 이런 긍정의 정서 외 에도 자녀가 학령기가 되면서 학군과 같은 물리적인 환경이 나 사교육의 기회 제공 등에 대한 압박감을 느끼는 어머니들 은 좌절감이나 우울감도 경험하였다. 이러한 결과는 부모로서 자녀에게 제공하는 기본적 생활을 위한 금전적 지출이 경제 적 어려움과 어머니의 불만족감으로 연결된다는 연구결과들 (Jackson et al., 2000; Zimmerman \& Easterlin, 2006)과도 유사한 맥락이다. 한국 사회의 과도한 교육열 속에서 자녀의 미래를 위한 인지교육이 자녀양육의 최우선 목표가 되면서, 사교육이 나 학원에 보내지 못하는 경우에는 부모로서의 의무를 다하지
못한다는 자책과 함께 좌절감을 경험하는 것으로 보인다. 그 러나 사교육의 수나 시간이 늘어날수록 아동의 스트레스는 증 가한다는 연구결과들(B. Kim, 2009; J. H. Lee, 2004; S.-H. Lee, Doh, Choi, \& Ku, 2010)에 기초할 때, 사교육을 보내지 못하는 데 대한 부모로서의 스트레스를 발견한 본 연구결과는 동시에 사교육을 너무 많이 받음으로써 자녀가 겪을 수 있는 스트레 스와 대비되어 좀 더 숙고할 만한 부분이기도 한다.

또한, 연구 참가자들 가운데 대부분의 어머니들은 자신의 양육에 대한 신념과 양육행동 간의 괴리가 생길 때 부정적 정 서를 경험하였다. 다시 말하면, 좋은 부모가 되고자 하는 마음 은 강하나 실천이 되지 않을 때, 죄책감을 경험하거나 양육에 대한 자신감이 떨어지는 것으로 보인다. 또한, 자신의 양육에 대한 주변의 평가에 민감하고, 이는 어머니 자신의 양육효능 감에 영향을 미치는 것으로 보였다. 이는 부모의 양육신념, 양 육행동 및 양육효능감의 간의 관련성을 발견한 선행 연구결과 (Seo \& Moon, 2008)와도 일치하는 것으로, 부모역할에 대한 건강한 양육신념이 바람직한 양육행동에 이어 높은 양육효능 감으로 연결될 수 있음을 시사한다. 무엇보다도, 자녀의 학령 기로의 진입은 부모들에게도 부모역할의 전환기가 된다는 점 에서 부모역할에 대한 다양한 정보가 혼재해 있는 사회에서 부모들은 오히려 혼란을 겪기 쉽다. 따라서 자녀의 발달단계 에 맞는 바람직한 부모역할의 신념을 가질 수 있도록 학교나 관련 기관에서 이를 지원할 수 있는 다양한 방안에 관심을 가 져야 할 것이다.

결론적으로, 유아기와는 달리 학령기로 진입하면서 학업적 수행이 더욱 더 강조되면서, 본 연구에 참가한 어머니들은 자 녀가 학교생활을 스스로 잘 할 수 있도록 자율성과 주도성을 키워줄 필요가 있다고 지각하였고, 이를 위해서는 조력자로서 의 부모역할이 무엇보다도 중요하다고 인식하였다. 이와 관련 하여 바람직한 부모역할에 대해 고민하였으며, 이러한 과정에 서 부모공동양육의 부재로 인해 주 양육자로서의 책임감이 가 중될 뿐만 아니라 자신의 비 일관된 양육행동으로 인해 혼란 을 겪고 있는 것으로 보였다. 또한, 자녀양육 과정에서 부모로 서의 원초적 기쁨과 같은 긍정적 정서 못지않게, 양육의 현실 에서 겪는 우울감, 불안감, 자책감과 좌절감과 같은 부정적 정 서 또한 상당하였다. 부모됨 경험과 관련하여 본 연구 참가자 들이 인식하는 인지적, 행동적, 정서적 측면을 종합해 보건대, 현 우리 시대의 국가적, 사회적 관심사로 급부상하고 있는 부 모교육의 활성화가 시급해 보인다.

본 연구의 제한점과 후속연구를 위한 제언을 덧붙인다면, 연구방법론적 측면에서 본 연구는 다수의 어머니들을 대상으 
로 1회의 개별 심층면접을 진행함으로써, 소수의 어머니들을 대상으로 하는 경우에 비해 상대적으로 심층적인 면접과 분 석을 시도하지 못하였다. 후속 연구는 소수의 어머니들을 대 상으로 수차례 면접방법을 이용하여 이러한 제한점을 보완할 수 있을 것이다. 또한, 본 연구는 12 명의 전업주부와 7 명의 취 업모를 연구 참가자로 선정하였음에도 불구하고 어머니의 취 업여부에 따른 비교를 시도하지 못하였다는 데 다소의 한계가 있다. 자녀양육의 물리적 측면에서의 차이를 고려할 때, 후속 연구에서는 전업주부와 취업모의 부모됨 경험을 비교분석해 보는 것도 의미 있을 것이다. 이 외에도, 본 연구는 주 양육자 로서의 어머니에 초점을 두고자 어머니들만을 연구대상으로 선정하였으나, 부모공동양육의 중요성에 근거하건대 후속 연 구에서는 아버지를 포함함으로써 아버지와 어머니 모두를 대 상으로 선정하는 것도 바람직할 것이다.

본 연구는 학령 초기 자녀를 둔 어머니들의 부모됨 경험과 관련하여 인지적, 행동적, 정서적 측면에서 접근함으로써 부 모역할의 의미와 어려움 그리고 이를 극복하기 위한 노력 등 에 대해 탐색해보았다는 데 의의가 있다. 이와 더불어, 부모됨 경험이 자녀의 성장과 발달뿐만 아니라 어머니 자신의 성인기 발달과 부부관계와도 밀접하게 관련됨을 확인할 수 있었다. 본 연구에서 도출된 주제와 의미는 학령기 부모교육 프로그램 을 포함하여 가족관계 향상을 위한 프로그램의 개발을 위한 기초 자료로서 활용될 수 있을 것이다.

\section{Acknowledgements}

This study was supported by the National Research Foundation of Korea grant funded by the Korean government (NRF2013S1A3A2055259).

\section{Note}

This article was presented at a paper session of the 2016 annual spring conference of the Korean Association of Child Studies.

\section{Conflict of Interest}

No potential conflict of interest relevant to this article was reported.

\section{References}

\section{In English}

Abidin, R. R. (1990). Introduction to the special issue: The stresses of parenting. Journal of Clinical Child Psychology, 19(4), 298-301. doi:10.1207/s15374424jccp1904_1

Abidin, R. R. (1992). The determinants of parenting behavior. Journal of Clinical Child Psychology, 21(4), 407-412. doi:10.1207/s15374424jccp2104_12

Ambert, A. (2001). The effect of children on parents. New York: Hawthorne.

Barry, T. D., Dunlap, S. T., Lochman, J. E., \& Wells, K. C. (2009). Inconsistent discipline as a mediator between maternal distress and aggression in boys. Child \& Family Behavior Therapy, 31(1), 1-19. doi:10.1080/07317100802701186

Belsky, J., Ward, M., \& Rovine, M. (1986). Prenatal expectations, postnatal experiences, and the transition to parenthood. In R. Ashmore \& D. Brodzinsky (Eds.), Thinking about the family (pp.139-145). Hillsdale, NJ: Erlbaum.

Bigner, J. J., \& Gerhardt, C. (2014). Parent-child relations: An introduction to parenting. NJ: Pearson.

Bornstein, M. H. (Ed.). (2002). Handbook of Parenting: Vol. 1. Children and parenting. Mahwah, NJ: Lawrence Erlbaum Associates Publishers.

Bornstein, M. H., \& Cote, L. R. (2006). Acculturation and parentchild relationships: Measurement and development. Mahwah, NJ: Lawrence Erlbaum Associates Publishers.

Bos, H. M., van Balen, F., \& van den Boom, D. C. (2004). Experience of parenthood, couple relationship, social support, and child-rearing goals in planned lesbian mother families. Journal of Child Psychology and Psychiatry, 45(4), 755-764. doi:10.1111/j.1469-7610.2004.00269.x

Bugental, D. B. (1992). Affective and cognitive processes within threat-oriented family systems. In I. E. Sigel, A. V. McGillicuddy-De Lisi, \& J. J. Goodnow (Eds.), Parental belief systems: The psychological consequences for children (2nd ed., pp. 219-248). Hillsdale, NJ: Lawrence Erlbaum Associate.

Clark-Stewart, K. A. (1988). Parents' effects on children's development: A decade of progress. Journal of Applied Developmental Psychology, 9(1), 41-84. doi:10.1016/0193-3973(88)90004-4

Cohen, E. (2004). Parental belief systems and difficulties in parenting: Using the parental awareness scheme as a therapeutic guide Journal of Infant, Child, and Adolescent Psychotherapy, 3(2), 252-269. doi:10.1080/15289160309348464

Collins, W. A., Madsen, S. D., \& Susman-Stillman, A. (2002). Parenting during middle childhood. In M. H. Bornstein (Ed.), Handbook of Parenting: Vol. 1: Children and parenting 
(pp. 73-101). Mahwah, NJ: Lawrence Erlbaum Associates Publishers.

Cowan, P. A., \& McHale, J. P. (1996). Coparenting in a family context: Emerging achievements, current dilemmas, and future directions. New Directions for Child and Adolescent Development, 74, 93-106. doi: 10.1002/cd.23219967408

Creswell, J. W., \& Miller, D. L. (2000). Determining validity in qualitative inquiry. Theory into Practice, 39(3), 124-130.

Crnic, K. A., \& Low, C. (2002). Everyday stresses and parenting. In M. H. Bornstein (Ed.), Handbook of Parenting: Vol. 5. Practical issues in parenting (pp. 243-267). Mahwah, NJ: Lawrence Erlbaum Associates Publishers.

Crosnoe, R., \& Cavanagh, S. E. (2010). Families with children and adolescents: A review, critique, and future agenda. Journal of Marriage and Family, 72(3), 594-611.

Crouter, A. C., Helms-Erikson, H., Updegraff, K., \& McHale, S. M. (1999). Conditions underlying parents' knowledge about children's daily lives in middle childhood: Between- and within- family comparisons. Child Development, 70(1), 246259. doi:10.1111/1467-8624.00018

Delmore-Ko, P., Pancer, S. M., Hunsberger, B., \& Pratt, M. (2000). Becoming a parent: The relation between prenatal expectations and postnatal experience. Journal of Family Psychology, 14(4), 625-640. doi:10.1037/08933200.14.4.625

Demick, J. (2002). Stages of parental development. In M. H. Bornstein (Ed.), Handbook of Parenting: Vol.3. Being and becoming a parent (pp. 389-413). Mahwah, NJ: Lawrence Erlbaum Associates Publishers.

Dix, T. (1991). The affective organization of parenting: Adaptive and maladaptive processes. Psychological Bulletin, 110(1), 3-25.

Dolan, R. J. (2002). Emotion, cognition, and behavior, Science, 298(5596), 1191-1194. doi:10.1126/science.1076358

Erikson, H. E. (1963). Childhood and society. New York: Norton.

Galinsky, E. (1981). Between generations: The six stages of parenthood. New York: Times Books.

Ganeson, K. (2006). Students' lived experience of transition into high school: A phenomenological study (Unpublished doctoral dissertation). Queensland University of Technology, Brisbane, Australia.

Glaser, B., \& Strauss, A. (1967). The discovery of grounded theory: Strategies for qualitative research. Chicago: Aldine.

Goldsteen, K., \& Ross, C. E. (1989). The perceived burden of children. Journal of Family Issues, 10(4), 504-526. doi:10.1177/019251389010004005

Goodnow, J. J. (2002). Parents' knowledge and expectations: Using what we know. In M. H. Bornstein (Ed.) Handbook of Parenting: Vol. 3. Being and becoming a parent (pp. 439-460). Mahwah, NJ: Lawrence Erlbaum Associates Publishers.
Haight, W. L., Parke, R. D., \& Black, J. E. (1997). Mothers' and fathers' belief about their toddlers' pretend play. MerrillPalmer Quarterly, 43(2), 271-290.

Harkness, S., \& Super, C. M. (Eds.). (1996). Parents' cultural belief systems: Their origins, expressions, and consequences. New York: Guilford Press.

Hoffenar, P. J., Balen, F., \& Hermanns, J. (2010). The impact of having a baby on the level and content of women's well-being. Social Indicators Reearch, 97(2), 279-295.

Hudson, D. B., Elek, S. M., \& Fleck, M. O. (2001). First-time mothers' and fathers' transition to parenthood: Infant care self-efficacy, parenting satisfaction, and infant sex. Issues in Comprehensive Pediatric Nursing, 24(1), 31-43. doi:10.1080/014608601300035580

Jackson, A. P., Brooks-Gunn, J., Huang, C., \& Glassman, M. (2000). Single mothers in low-wage jobs: Financial strain, parenting, and preschoolers' outcomes. Child Development, 71(5), 1409-1423. doi:10.1111/1467-8624.00236

Kochanska, G., Kuczynski, L., \& Radke-Yarrow, M. (1989). Correspondence between mothers' self-reported and observed child-rearing practices. Child Development, 60(1), 56-63. doi: $10.2307 / 1131070$

Laursen, B., \& Collins, W. A. (2009). Parent-child relationships during adolescence. In R. M Lerner \& L. Steinberg (Eds.), Handbook of Adolescent Psychology: Vol. 2. Contextual influences on adolescent development (3rd ed., pp. 3-42). Hoboken, NJ: John Wiley \& Sons.

Lench, H. C., Flores, S. A., \& Bench, S. W. (2011). Discrete emotions predict changes in cognition, judgment, experience, behavior, and physiology: A meta-analysis of experimental emotion elicitations. Psychological Bulletin, 137(5), 834-855. doi: $10.1037 / \mathrm{a} 0024244$

Maccoby, E. (1980). Social development: Psychological growth and the parent-child relationship. San Diago, CA: Harcourt Brace Jovanovich.

Montemayor, R. (1983). Parents and adolescents in conflict: All families some of the time and some families most of the time. Journal of Early Adolescence, 3(1-2), 83-103.

Myrskyla, M., \& Margolis, R. (2014). Happiness: Before and after the kids. Demography, 51(5), 1843-1866. doi:10.1007/ s13524-014-0321-x

Nelson, S. K., Kushlev, K., \& English, T., Dunn, E. W., \& Lyubomirsky, S. (2013). In defense of parenthood: Children are associated with more joy than misery. Psychological Science, 24(1), 3-10. doi:10.1177/0956797612447798

Nelson, S. K., Kushlev, K., \& Lyubomirsky, S. (2014). The pains and pleasures of parenting: When, why, and how is parenthood associated with more or less well-being? Psychological Bulletin, 140(3), 846. doi:10.1037/a0035444

Newberger, C. M. (1980). The cognitive structure of parenthood: 
Designing a descriptive measure. New Directions for Child Development, 7, 45-67. doi:10.1002/cd.23219800705

Nomaguchi, K. M. (2012). Parenthood and psychological wellbeing: Clarifying the role of child age and parent-child relationship quality. Social Science Research, 41, 489-498. doi:10.1016/j.ssresearch.2011.08.001

Nomaguchi, K. M., \& Brown, S. L. (2011). Parental strains and rewards among mothers: The role of education. Journal of Marriage and Family, 73(3), 621-636. doi:10.1111/j.17413737.2011.00835.x

Pancer, S. M., Pratt, M., Hunsberger, B., \& Gallant, M. (2000). Thinking ahead: Complexity of expectations and the transition to parenthood. Journal of Personality, 68(2), 253280. doi:10.1111/1467-6494.00097

Patterson, G. R., \& MacCoby, E. E. (1980). Mothers: The unacknowledged victims. Monographs of the Society for Research in Child Development, 45(5), 1-64. doi:10.2307/1165841

Prior, M., Sanson, A., Carroll, R., \& Oberklaid, F. (1989). Social class differences in temperament ratings of preschool children. Merrill-Palmer Quarterly, 35(2), 239-248.

Repokari, L., Punamäki, R. L., Poikkeus, P., Tiitinen, A., Vilska, S., Unkila-Kallio, L., . . . Tulppala, M. (2006). Anteand perinatal factors and child characteristics predicting parenting experience among formerly infertile couples during the child's first year: A controlled study. Journal of Family Psychology, 20(4), 670-679. doi:10.1037/08933200.20.4.670

Rholes, W. S., Simpson, J. A., \& Friedman, M. (2006). Avoidant attachment and the experience of parenting. Personality and Social Psychology Bulletin, 32(3), 275-285. doi:10.1177/0146167205280910

Rowe, M. L. (2008). Child-directed speech: Relation to socioeconomic status, knowledge of child development and child vocabulary skill. Journal of Child Language, 35(1), 185-205. doi:10.1017/S0305000907008343

Sigel, I. E. (1985). Parental belief systems. Hillsdale, NJ: Erlbaum.

Sigel, I. E., \& McGillicuddy-De Lisi, A. V. (2002). Parental beliefs and cognitions: The dynamic belief systems model. In M. H. Bornstein (Ed.), Handbook of Parenting: Vol 3. Status and social conditions of parenting (pp. 485-508). Mahwah, NJ: Lawrence Erlbaum.

Simons, R. L., Whitbeck, L. B., Conger, R. D., \& Chyi-In, W. (1991). Intergenerational transmission of harsh parenting. Developmental Psychology, 27(1), 159-171. doi:10.1037/0012-1649.27.1.159

Umberson, D., Pudrovska, T., \& Reczek, C. (2010). Parenthood, childlessness, and well-being: A life course perspective. Journal of Marriage and Family, 72(3), 612-629. doi:10.1111/j.1741-3737.2010.00721.x

Wolcott, H. (2001). Writing up qualitative research (2nd ed.).
Thousand Oaks, CA: Sage Publication.

Wood, E., Desmarais, S., \& Gugula, S. (2002). The impact of parenting experience on gender stereotyped toy play of children. Sex Roles, 47(1-2), 39-49. doi:10.1023/ A: 1020679619728

Zimmerman, A., \& Easterlin, R. A. (2006). Happily ever after? Cohabitation, marriage, divorce and happiness in Germany. Population and Development Review, 32(3), 511-528. doi:10.1111/j.1728-4457.2006.00135.x

\section{In Korean}

Chi, S.-A. (2010). A study on kindergarten parents' recognition and current states of kindergarten-elementary school linkage education. Early Childhood Education Research \& Review, 14(2), 217-248.

Choi, S. (2015). A study of the intergenerational transmission of positive parenting behavior and authoritative parenting belief: Focused on mothers of preschool children (Unpublished master's thesis). Ewha Womans University, Seoul, Korea.

Choi, S.-E. (2009). Parent's perception and performance of father's role for young children (Unpublished master's thesis). Kyungnam University, Changwon, Korea.

Chung, O.-B., Chung, S.-H., Kim, K.-E., \& Park, Y.-J. (2007). A study on the differences of family values and parental role responsibility among three generations. Journal of Family Relations, 12(2), 215-249.

Doh, H.-S. (2012). The first parenting book. Seoul: Jisikchannel.

Doh, H.-S., Lee, H.-S., Kim, S.-H., Choi, M.-K., \& Lee, S. (2011). Human development and the famly. Seoul: Gyomoon Publisher.

Ha, M. J., \& Jang, Y. A. (2010). The effect of parenting efficacy, parenting stress on self-efficacy and daily stress among elementary school children. Korean Journal of Community Living Science, 21(1), 33-51.

Han, E.-G., \& Kim, S.-A. (2007). A study on fair parental role model of dual earner couples, their expectation for parental nursing capability and real nursing practices. Journal of Korean Home Management Association, 25(2), 37-46.

Huh, H. G. (2014). Research on parents' concerns and involvement during transition from preschool to elementary school. Korean Journal of Early Childhood Education, 34(2), 435-453.

Jun, C. A., \& Park, S. Y. (1996). The effect of parenting stress and social support on marital satisfaction. Family and Environment Research, 34(5), 115-129.

Jung, D.-H., \& Ji, S.-A. (2006). A study of the relationships among children's peer interactions, child-teacher relationships, multiple intelligences, and elementary school adjustment. Korean Journal of Early Childhood Education, 26(3), 201-221. 
Kee, C. Y., Shin, H. S., \& Hong, K. J. (2009). The relationships among children's stress, self-encouragement and psychological maladjustment. Korean Journal of Play Therapy, 12(4), 117-133.

Keum, J., \& Kim, D. (2014). The casual relationship among the father's participation in childcare, job satisfaction, parenting stress, and marital satisfaction of working mother. Family and Environment Research, 52(2), 141-150.

Kim, B. (2009). The influence from extracurricular study of academic stress and academic achievement (Unpublished master's thesis). Yonsei University, Seoul, Korea.

Kim, H.-J., \& Jung, H. S. (2014). A qualitative study on the acceptance of disabilities of mothers of with autistic spectrum disorder. Ewha Journal of Social Sciences, 30(1), 279-316.

Kim, I. J., \& Lee, S. H. (2005). Motherhood ideology and parental satisfaction among mothers with pre-school children. Journal of Family Relations, 10(3), 1-25.

Kim, J.-H. (2005). Role performance and self-confidence in the fathers with elementary school children. Journal of Korean Home Management Association, 23(1), 113-123.

Kim, J.-H., Doh, H.-S., Shin, N., \& Kim, M.-J. (2011). The mediating roles of mothers' psychological well-being and support/control in the relationship between maternal childrelated stress and adolescents' school adjustment. Journal of Korean Home Management Association, 29(4), 217-232.

Kim, K. H., \& Cho, B. H. (2000). An ecological approach to analysis of variables in the parenting stress of the dual-earner mothers and fathers. Korean Journal of Child Studies, 21(4), 35-50.

Kim, S. J., Song, S.-M., Doh, H.-S., Shin, N., Kim, M.-J., \& Kim, E. H. (2015). A qualitative study to the mother's role experiences during their child's transition from early childhood to middle childhood. Korean Journal of Child Studies, 36(2), 111-130.

Kim, S. M. (2004). A qualitative study on the full-time housewife's everyday child caring and education experience. Korean Journal of Human Ecology, 13(4), 537-553.

Kim, S. Y., \& Noh, J. W. (2016, May 2). "I am sorry I couldn't meet your expectations." Children discouraged by the mothers' scolding. Donga.com News. Retrieved from http:// news.donga.com.

Ko, Y. H. (2001). Demographic variables and the relations between maternal beliefs and child-rearing behaviors: A focus on mothers of 2- to 3-year-old (Unpublished master's thesis). Ewha Womans University, Seoul, Korea.

Korea Institute for Health and Social Affairs. (2012). The Survey on the national fertility, family health and welfare in Korea. Sejong: Korea Institute for Health and Social Affairs.

Korea Institute of Childhood and Education. (2008). Korean parents' perspectives on childrearing. Seoul: Korea Institute of
Childhood and Education.

Lee, J.-A., \& Chung, H.-H. (2012). A short-term longitudinal study on the structural relations among children's daily hassles, cognitive vulnerability and depression. Korean Journal of Counseling, 13(2), 935-952.

Lee, J. H. (2004). A study on the effects of private tutoring and parent's child-rearing attitudes on children's learning stress/ attitudes/performances (Unpublished master's thesis). Hanyang University, Seoul, Korea.

Lee, J. S. (2003). Fathers of preschool: Childrearing involvement, husband-wife relationship and growth as a parent. Korean Journal of Child Studies, 24(3), 99-108.

Lee, S.-E., \& Park, S.-Y. (2012). Parenting knowledge, attributions and the perceptions of parenting roles as they related to the parenting behaviors of mothers' towards their infants. The Korean Journal of the Human Development, 19(2), 131-149.

Lee, S.-H., Doh, H.-S., Choi, M.-K., \& Ku, S.-K. (2010). Exploring pathways from mother's beliefs to children's subjective well-being: The mediating effects of children's private after school education and stress levels. Korean Journal of Child Studies, 31(3), 255-272.

Lee, Y.-O., \& Lee, J.-S. (2011). A study of the difference by development stages on daily stress, perceived environment, psychological problem of child-adolescents. Korean Journal of Child Psychotherapy, 6(1), 53-79.

Lee. W., \& Hyun, O. K. (1999). A comparative study of mothers' and grandmothers' infant/toddler rearing beliefs. Journal of Korean Home Economics Association, 37(4), 97-110.

Ok, K. H., \& Kim, M. H. (2015). The effects of parenting beliefs and supportive interaction on mothers' parenting stress of young children: Variations by income level and employment status. Korean Journal of Childcare and Education, 11(1), 461-480. doi:10.14698/jkcce.2015.11.461

Park, J. (2014). A study of the socio-cultural environment of childbirth and childrearing. Sejong: Korea Institute for Health and Social Affairs.

Park, J. (2015). A study of the relationship between father's and mother's coparenting and ego-resilience of their child (Unpublished master's thesis). Ewha Womans University, Seoul, Korea.

Park, S. Y. (2005). A study on maternal attributions, perceptions of parental role, and parenting knowledge of infants' mothers (Unpublished master's thesis). Ewha Womans University, Seoul, Korea.

Park, S.-Y., Doh, H.-S., Kim, M.-J., \& Song, S.-M. (2014). The effects of maternal grandmothers' positive parenting behavior, mothers' emotion regulation and positive parenting behavior on children's emotion regulation. Korean Journal of Child Studies, 35(2), 117-136.

Park, Y., Choi, M., Yang, M., Na, J., \& Kim, M. (2005). Child 
rearing in contemporary society. Seoul: Hakjisa.

Seo, K. N., \& Moon, H. J. (2008). Mothers' beliefs in developmentally appropriate practice: Relationships with mother's childhood experience, parenting efficacy and parenting behavior. Korean Journal of Child Studies, 29(3), 23-40.

Sohn, S. M. (2012). Parenting stress and related factors of employed and non-employed mothers with infants. Journal of Future Early Childhood Education, 19(1), 331-357.

Song, S.-M., Doh, H.-S., Kim, M.-J., Kim, S., Yun, K. B., \& Kim, J. E. (2014). A phenomenological approach to experiences of young children's mothers on respected parents \& respected children parent education program. Journal of Korean Child Care and Education, 10(4), 133-158.

Statistics Korea. (2016) 2015 statistics of marriage and divorce. Retrieved from http://kostat.go.kr/portal/korea/kor_nw/3/ index.board?bmode $=$ read $\& a S e q=352515$

Um, K.-A., \& Yang, S.-E. (2011). A qualitative study on the career interrupted and the child care of married women. Journal of Korean Home Management Association, 29(1), 21-40.

Won, J.-S. (1989). A study on the parenthood transition (Unpublished master's thesis). Ewha Womans University, Seoul, Korea.
Woo, N. (2013). Living as a parent in the contemporary society. The Society for Open Parent Education Conference, 10, 11-19.

Yee, Y.-H. (2008). Multiple determinants of father involvement: Measuring mother and father shared caregiving. Journal of Korea Council for Children \& Rights, 12(2), 189-210.
Hyun-Sim Doh

Seung-Min Song

Woon Kyung Lee

Min-Jung Kim

Nana Shin

Tae Woo Kim

\section{ORCID}

http://orcid.org/0000-0002-7393-4520

http://orcid.org/0000-0002-8931-8327

http://orcid.org/0000-0002-2221-1787

http://orcid.org/0000-0002-6591-9419

http://orcid.org/0000-0002-7869-6875

http://orcid.org/0000-0002-1208-0293
Received April 30, 2016

Revision received June 17, 2016

Accepted June 20, 2016 